\title{
Circulair Werelddorp Diamondiaal
}

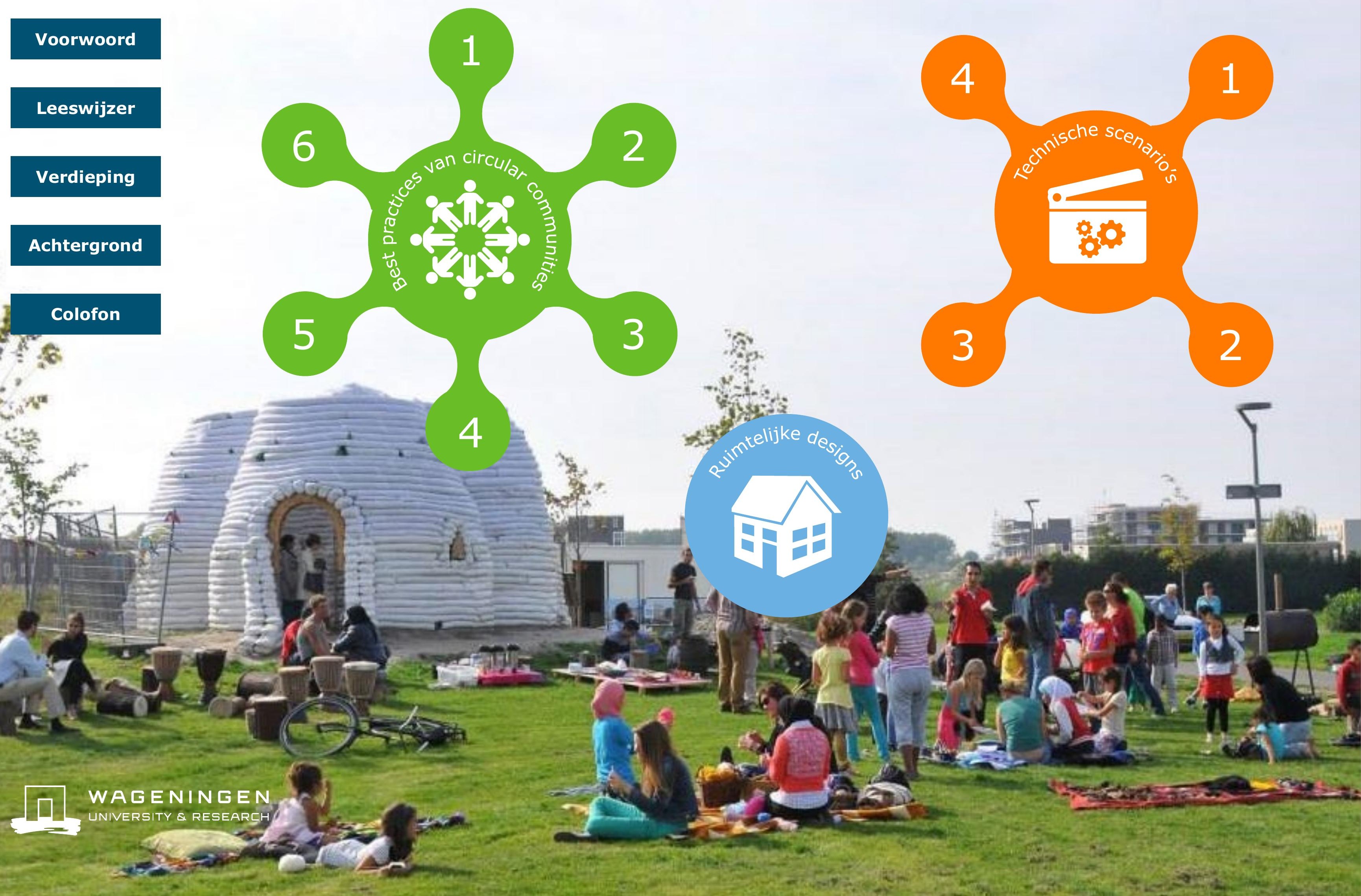




\section{Voorwoord}

Oosterwold is een bijzondere ontwikkeling in Flevoland vanwege de geplande omvang, de doorlooptijd en de afwijkende manier van gebiedsontwikkeling. De ontwikkeling van Oosterwold vindt op 'organische' wijze plaats. Er is op voorhand geen eindbeeld voor het ontwikkelde gebied.

Ook de wijze waarop we als Waterschap betrokken zijn bij diverse initiatieven gaat op een "organische' manier. Zeker bij de aanvang van initiatieven c.q. planvormingsprocessen zijn we soms als adviseur betrokken.

Bij het project Diamondiaal ben ik op grond van persoonlijke contacten met Wageningen University benaderd om mee te denken bij dit project.

Een project als Oosterwold, Diamondiaal kan wat mij betreft alleen succesvol zijn als we als betrokken personen, ieder vanuit zijn eigen positie, samenwerken. Uiteindelijk willen we met elkaar natuurlijk een adequate afvalwaterverwerking realiseren voor nu en in de toekomst.

Met name de ongewisse situatie van de toekomst maakt het spannend en uitdagend om nu al hierop vooruit te lopen en nieuwe wegen (afvalwaterstromen) te bewandelen om te verkennen wat er allemaal mogelijk.

Ik wens Diamondiaal succes met het realiseren van hun wensen en mogelijk kan het project Diamondiaal een inspiratiebron zijn voor verdere vernieuwing in Oosterwold.

Met vriendelijke groet,

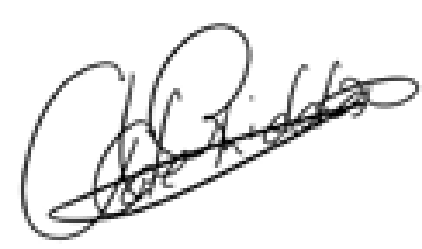

Rien de Ridder

Beleidsadviseur Waterketen

Waterschap Zuiderzeeland
Voorwoord

Leeswijzer

Verdieping

Achtergrond

Colofon

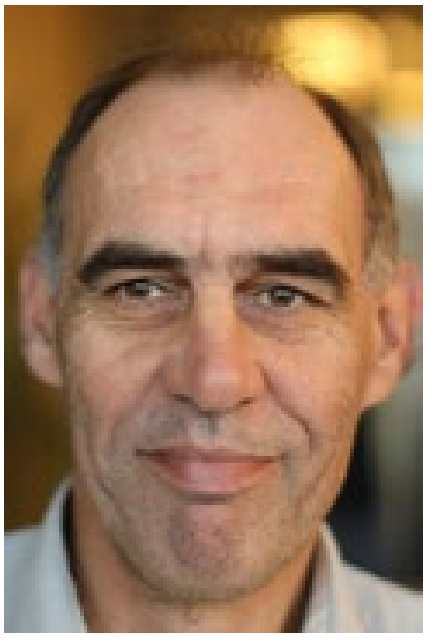




\section{Voorwoord}

Ruim 5 jaar geleden zijn Amal Abbass-Saal en Sandra Manintveld begonnen om duizenden nieuwe en oude Almeerders van alle leeftijden te vragen wat zij nodig hebben om zich echt thuis te voelen in Nederland.

Zij presenteerden de tentoonstellingen: 'Thuis, als een spiegel van jezelf' en 'Thuisland' in het voormalige

Architectuurcentrum van Almere. Beide bestuursleden van Stichting Inspiratie Inc. namen daarna het initiatief om de collectieve droom van een werelddorp verder te ontwikkelen. In samenwerking met Coöperatief Woonfonds Meerwonen, Denktank Diamondiaal, Triodos Bank, Wetenschapswinkel Wageningen Universiteit, Amsterdam Institute for Advanced Metropolitan Solutions, Atelier Dutch en het Kansfonds kwam de nieuwe Wooncoöperatie Diamondiaal tot stand. Wat ooit begon als een droom wordt nu werkelijkheid, een thuis creëren voor mensen van over de hele wereld".

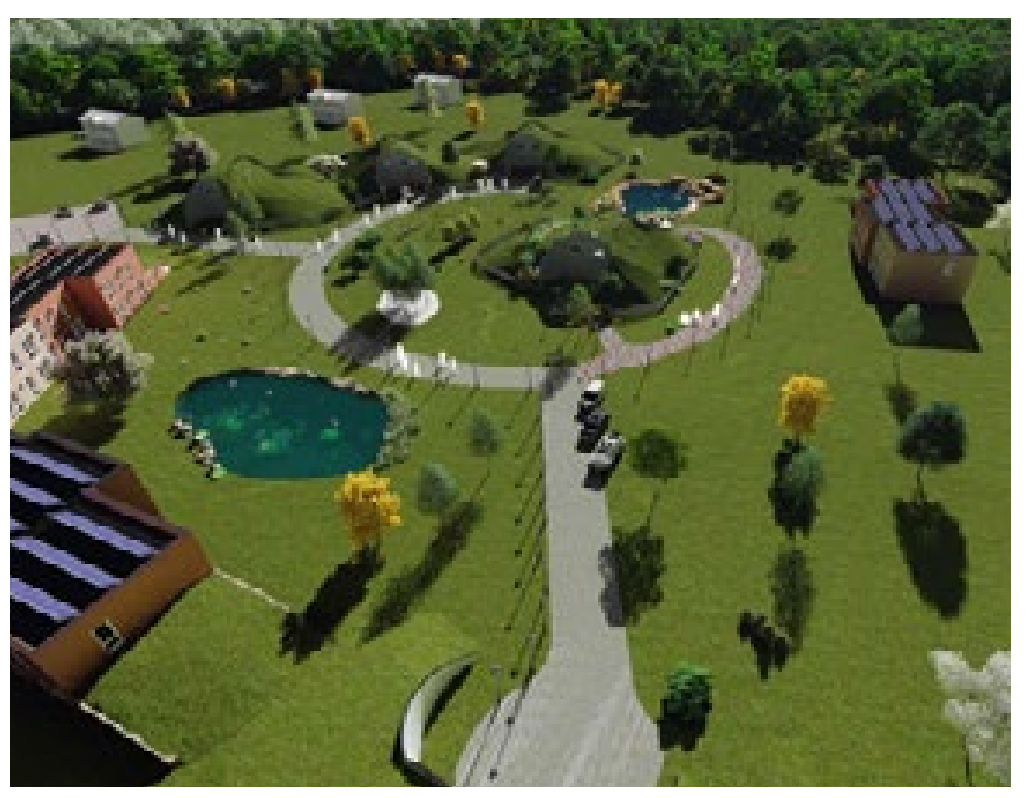

\section{Stefan van Uffelen}

bestuurder van Co-operatieve woonfonds Woonmere

'Eind november 2017 begonnen de eerste werkzaamheden van de bouw van $2200 \mathrm{~m} 2$ woonruimte verdeeld over 4 woningen, 3 woongebouwen en een BurrT-Thuis. Op de kavels komen verder twee vijvers, een sloot, een helofytenfiltersysteem en een zijstraat met een parkeerplaats.'

De zijstraat heet Bostuin en verwijst naar de toekomstige Permacultuur Voedselbostuin.

\section{Tom Saal}

Director woon co-operatie Diamondiaal

'Mensen en organisaties kunnen zich hier vanaf de zomer 2018 verder ontplooien in een nieuw en bruisend werelddorp waar iedereen welkom is; een thuisplek in Almere waar gelijkwaardigheid, verbinding en inclusie hoog in het vaandel worden gedragen."

Diamondiaal geldt als een 'best practice' van inclusieve circulaire gebiedsontwikkeling bottom up. Om mee inzicht te krijgen in de ruimtelijke, sociale en technische mogelijkheden om een circulaire woon- \& werkgemeenschap op te zetten is de Wetenschapswinkel Wageningen benaderd. De Wetenschapswinkel Wageningen heeft het mogelijk gemaakt dat toekomstige bewoners van Diamondiaal samen met onderzoekers en studenten van Wageningen University scenario's hebben ontwikkeld voor een duurzame woon- en werkgemeenschap Diamondiaal in Oosterwold (Almere). Een mooi voorbeeld van co-creatie. 


\section{Leeswijzer}

Voorwoord

Leeswijze

Verdieping

Achtergrond

Colofon

Deze publicatie bestaat uit de volgende onderdelen:

\section{Resultaten}

- 'Best Practices'

- Technische scenario's

- Ruimtelijk ontwerpen

\section{Verdieping}

Onderbouwing van de technische scenario's, ruimtelijke ontwerpen en voorbeelden van

'best practices' die de besluitvorming over hoe Circulair Werelddorp Diamondiaal ontwikkeld kan worden, ondersteunt.

\section{Achtergrond}

Achtergrond over het onderzoeksproject 'Circulair Werelddorp Diamondiaal', de diversiteit aan onderzoeksmethoden en hoe deze publicatie tot stand is gekomen. 


\section{Verdieping}

'Best Practices'

Link naar Towards Circular Villages

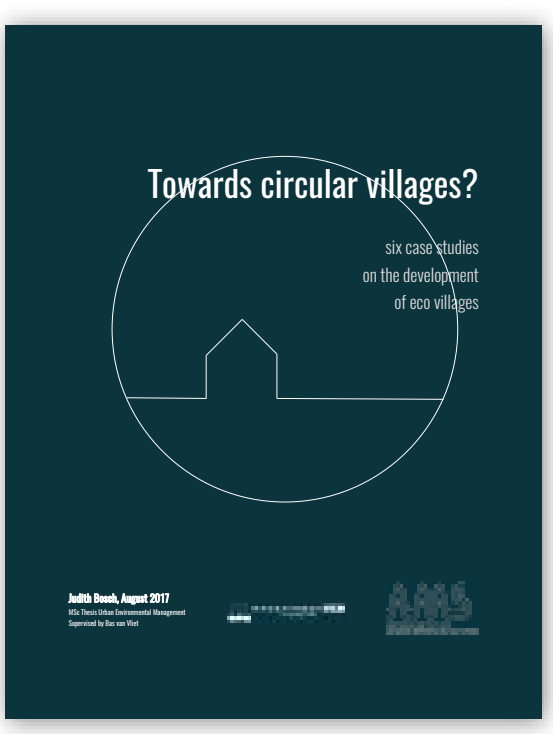

Technische scenario's

Link naar Compendium

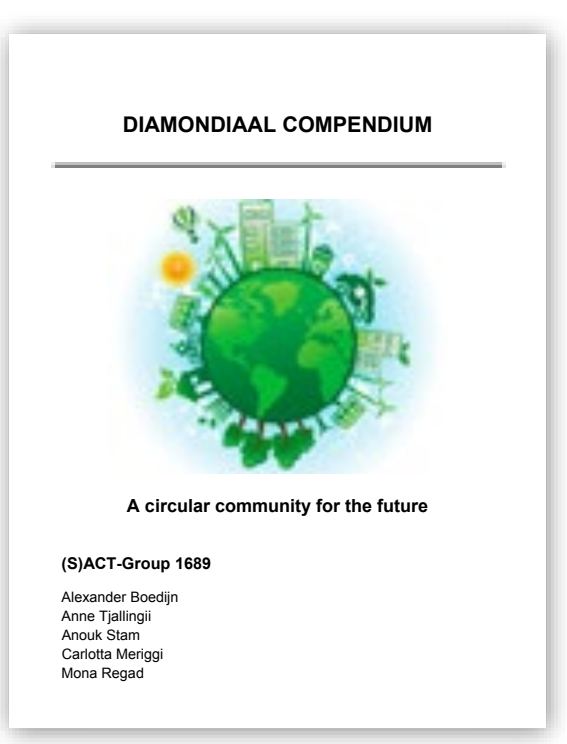

Ruimtelijk ontwerp

Link naar Background report \& perm culture plan

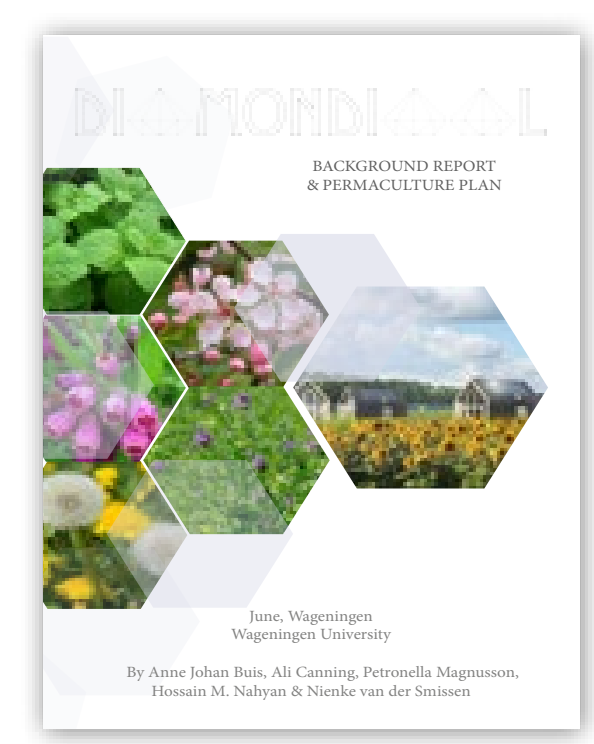

Voorwoord

Leeswijzer

Verdieping

Achtergrond

Colofon

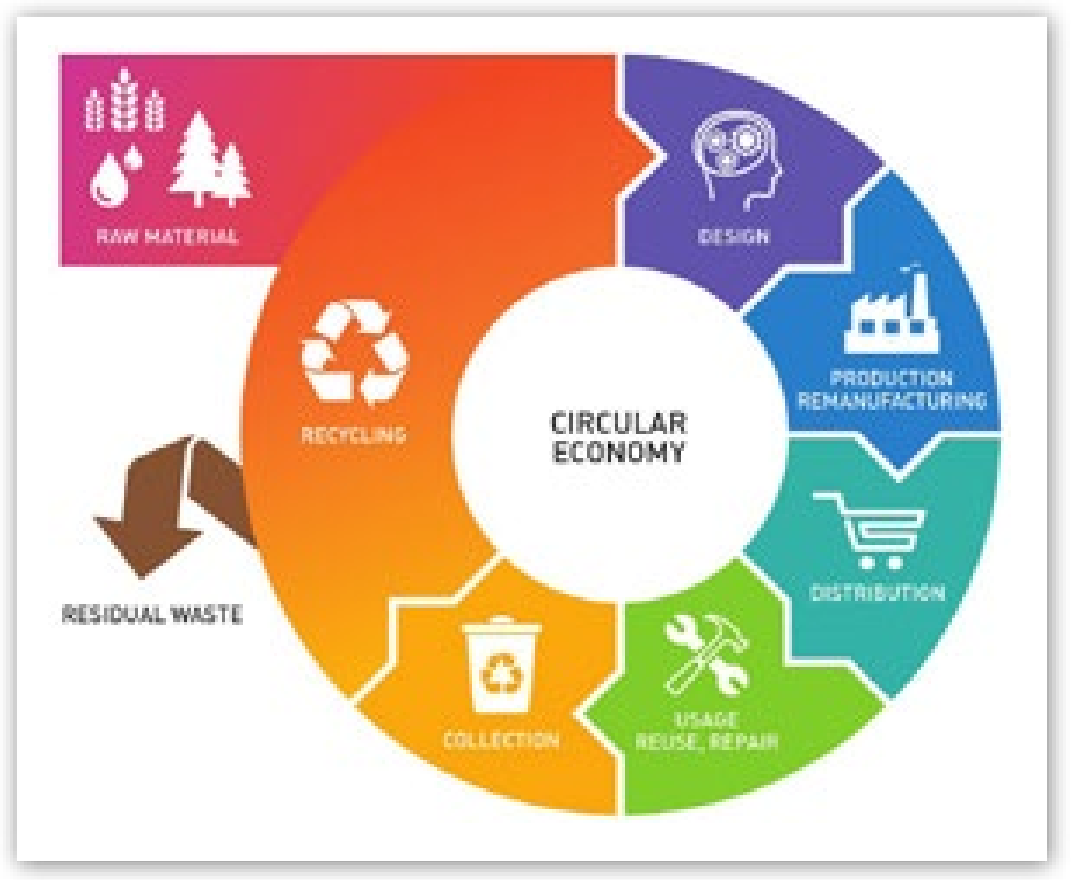




\section{Circulair Werelddorp Diamondiaal}

'Allemaal delen we dezelfde droom: een wereld waar iedereen naar vermogen actief aan bijdraagt, ongeacht talenten, beperkingen, cultuur, religie, leeftijd of gender. Een wereld waarin diversiteit als kracht en bron van inspiratie fungeert en niet als probleem. Dat is de wereld waar Stichting Inspiratie Inc. naar toe werkt en waar 'Diamondiaal' voor staat'.

Stichting Inspiratie Inc. bestaat uit een actief netwerk, dat zich kenmerkt door culturele en religieuze diversiteit en een grote onderlinge betrokkenheid. Dagelijks worden activiteiten georganiseerd op het gebied van kunst en cultuur, koken, taal en natuur. Hierdoor wordt op creatieve wijze de diversiteit binnen Nederland zichtbaar gemaakt met veerkracht, participatie en sociaal ondernemerschap als belangrijkste pijlers. Eén van de belangrijkste groepen die deelnemen aan deze activiteiten zijn mensen die nieuw in Nederland integreren.

De impact van de activiteiten van Inspiratie Inc. is nu al verstrekkend en groeit gestaag. Er wordt samengewerkt met tal van organisaties op het gebied van participatie, preventieve gezondheidszorg, activering, sociale cohesie en internationale educatie. Hierdoor is er steeds meer behoefte aan een nieuwe eigen woon- \& werkplek. Een plek die kan functioneren als broedplaats voor sociaal ondernemerschap en waar tegelijkertijd het hergebruik van producten en grondstoffen centraal staat, waar afval en schadelijke emissies naar bodem, water en lucht zo veel mogelijk wordt voorkomen door het sluiten van kringlopen. Inmiddels is in samenwerking met de gemeente Almere grond in Oosterwold gekocht waarop Inspiratie Inc is begonnen met het bouwen van een 'Circulair Werelddorp Diamondiaal.'

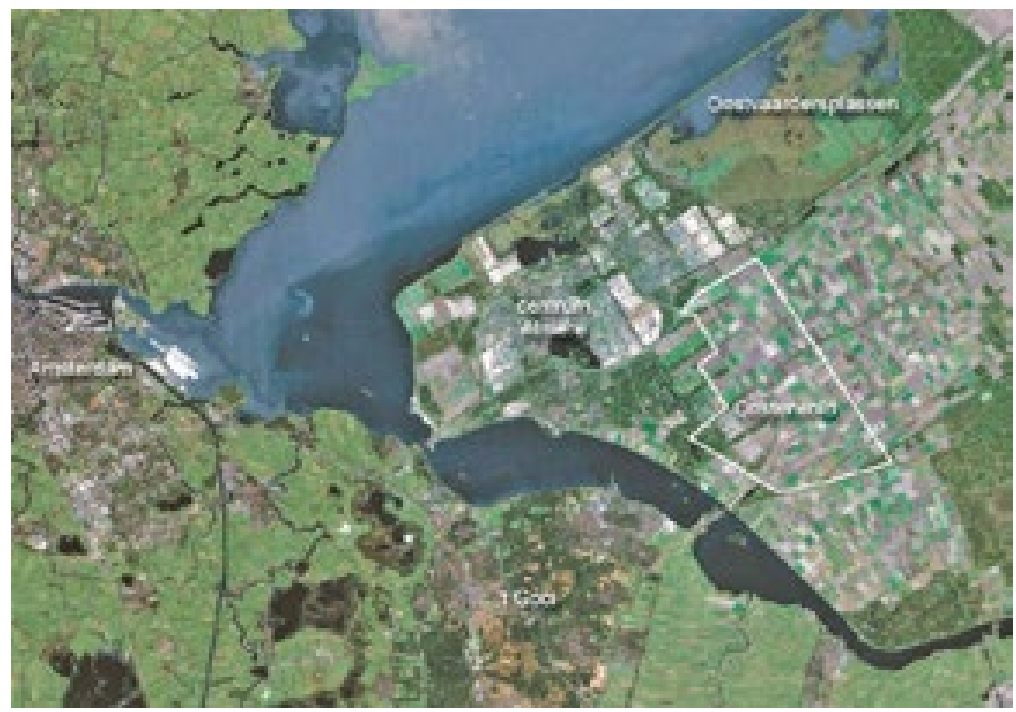

Oosterwold

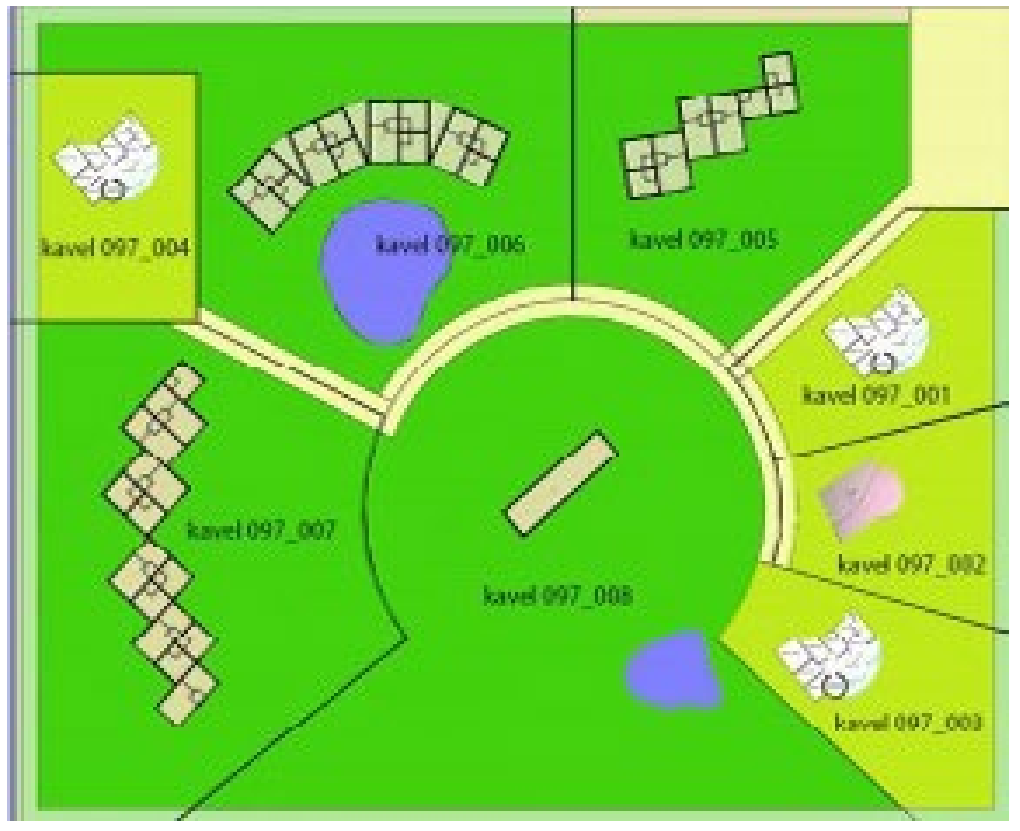

Diamondaal
Voorwoord

Leeswijzer

Verdieping

Achtergrond

Colofon

Deze publicatie is het resultaat van het Wetenschapswinkelproject 'Circulair

Werelddorp Diamondiaal' uitgevoerd in opdracht van de Stichting Inspiratie Inc.

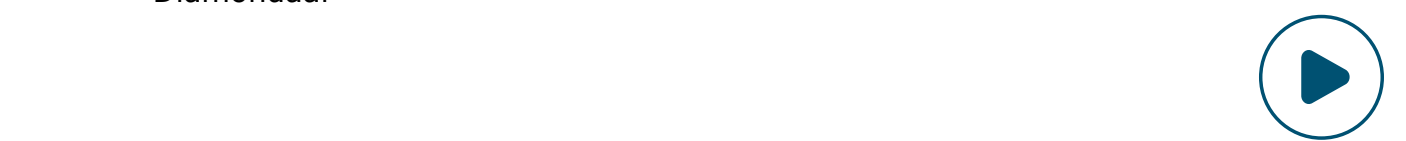




\section{Sociale, Technische \& Ruimtelijke Scenario's}

Deze publicatie beschrijft sociale, technische en ruimtelijke scenario's om een circulaire woon- en werkgemeenschap op te zetten in Oosterwold (Almere). De scenario's zijn gebaseerd op (1) 'best practices' van bestaande initiatieven op het gebied van circulaire woon- \& werk-gemeenschappen (ecovillages). Een ecovillage is een woon- en werkgemeenschap, waarin mensen participeren, samenwerken en innoveren, ecologische, sociale, culturele en economische dimensies van duurzaamheid integreren en de impact op de sociale en natuurlijke omgeving verminderen. Deze manier van leven bevordert het welzijn van mensen en ecosystemen.

De 'Best Practices' tonen aan dat sociale cohesie cruciaal is voor het functioneren van een ecovillage en nodig om ecologische en sociale doelen te bereiken. Sociale cohesie kan bereikt worden door het organiseren van sociale activiteiten, het creëren van gezamenlijke faciliteiten, zoals een gedeelde fietsenstalling, een pizza oven en een schuttingvrij beleid om betrokkenheid te

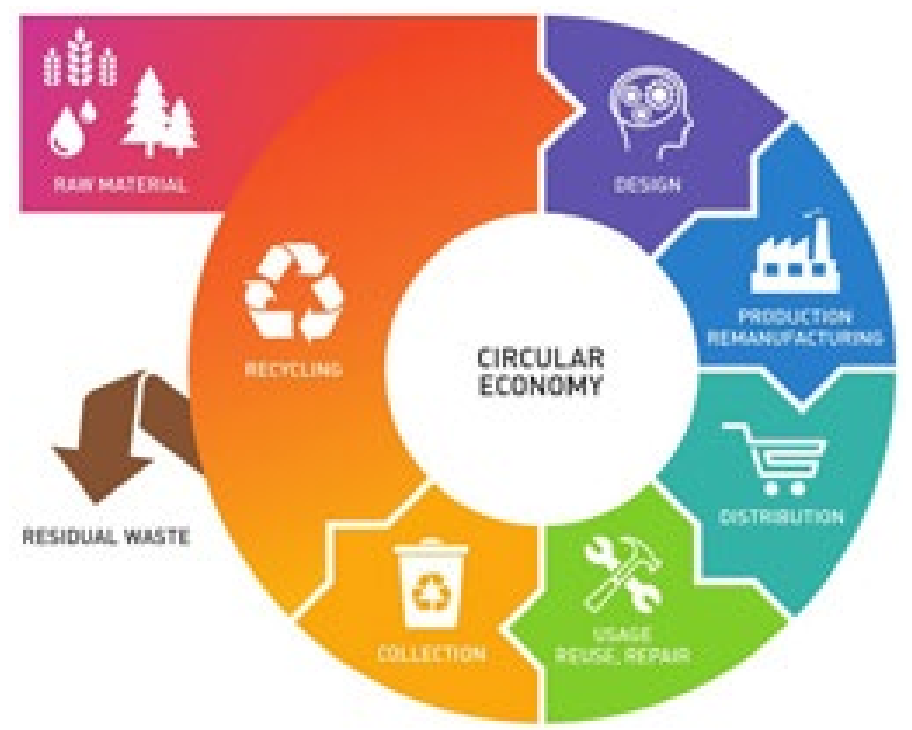

bevorderen. Ook is het belangrijk dat er helder wordt gecommuniceerd over de visie en de verwachtingen, dat er een horizontale organisatie structuur wordt opgezet waarbij alle bewoners zich uitgenodigd voelen om mee te denken, van elkaar te leren en te experimenteren met innovatieve vormen van duurzame ontwikkeling op sociaal, technisch en ruimtelijk gebied.

(2) Een technisch ontwerp over hoe duurzame technologieën in relatie tot water, energie, \& voedselproductie kunnen bijdragen aan off-grid en circulaire doelstellingen van Diamondiaal. Elk scenario rankt, naast een beschrijving van de voor- en nadelen van een bepaalde technologie, de haalbaarheid van deze technologie. Hierdoor wordt het besluitvormingsproces over welke technologieën geïmplementeerd kunnen worden in Oosterwold ondersteund. De scenario's laten zien dat de keuze voor een bepaalde technologie samenhangt met vraagstukken als kiezen voor externe afhankelijkheid of gebruik maken van interne aanwezige specialistische kennis en van het vrij laten om

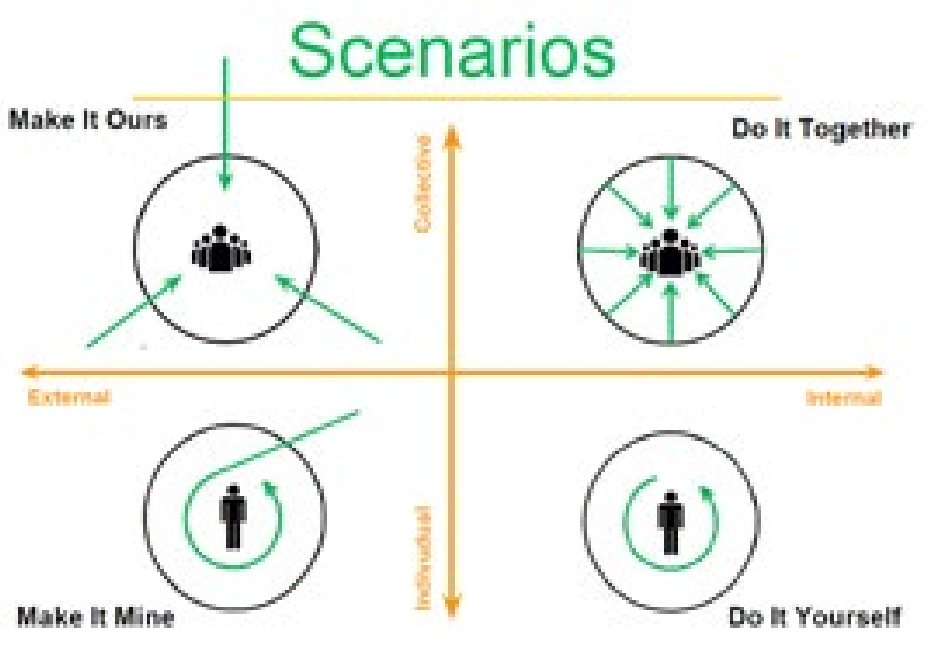

Voorwoord

Leeswijzer

Verdieping

Achtergrond

Colofon

Deze publicatie is het resultaat van het Wetenschapswinkelproject 'Circulair

Werelddorp Diamondiaal' uitgevoerd in opdracht van de Stichting Inspiratie Inc. 
individuele keuzes te maken tot het nemen van collectieve besluiten.

(3) Een ruimtelijk ontwerp voor Oosterwold, waarbij de verbinding stad- en natuur en de verbinding wonenen werken centraal staan. Tijdens een workshop georganiseerd door studenten van Wageningen University is samen met toekomstige bewoners geprobeerd een gemeenschappelijke visie op de ruimtelijke ontwikkeling van circulair werelddorp Diamondiaal vorm te geven. Centraal staan landschappelijke elementen, -functies en -activiteiten in relatie tot wonen $\&$ werken. Welke publieke- en welke private ruimtes vinden bewoners wenselijk in hun nieuwe woon- \& werkomgeving. De resultaten van de workshop tonen verschillende cirkels. In cirkel 1 kiezen bewoners voor privé tuinen met omheining; cirkel 2 biedt ruimte voor permacultuur, waterelementen, (fiets)

\section{Methode}

Centraal staat de onderzoeksvraag: Welke ruimtelijksociaal- en technisch haalbare scenario's ondersteunen Diamondiaal bij het ontwikkelen van een circulaire woon-

\& werkgemeenschap in Oosterwold in Almere?

- Welke factoren zijn bepalend voor de kans op succes bij vergelijkbare initiatieven op het gebied van circulaire woon- $\&$ werkgemeenschappen?

- Welke innovatieve technologieën op het gebied van water, energie en voedsel kunnen een circulaire woon$\&$ werkgemeenschap optimaliseren?

- Welke ruimtelijke opties op het gebied van water, energie en voedsel kunnen een circulaire woon- \& werkgemeenschap optimaliseren?

Deze publicatie en bijbehorende 'best practices', technische scenario's en een ruimtelijk ontwerp is tot stand gekomen door literatuuronderzoek, interviews met paden. Cirkel 3 is open voor sport faciliteiten, religieuze ontmoetingsplekken, kippen en bloembedden. In cirkel 4 staan kunst, muziek en andere culturele activiteiten centraal, de natuur mag iets ruiger zijn met bomen

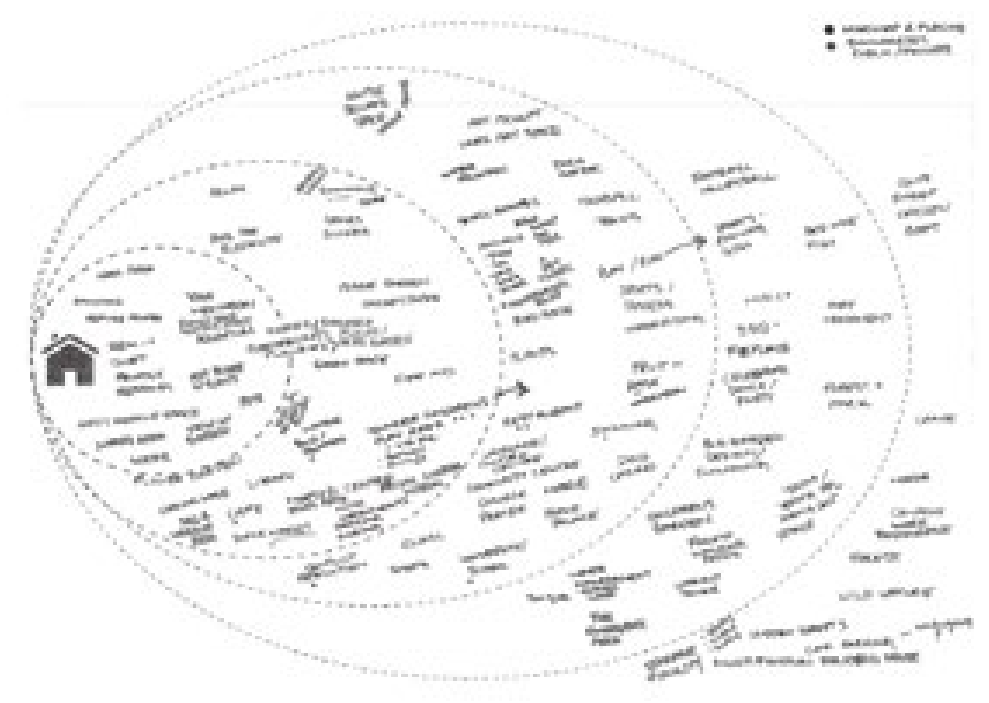

technische experts, bewoners van eco-villages en toekomstige bewoners van Diamondiaal, excursies, bezoeken aan Oosterwold, workshops en

discussiebijeenkomsten met betrokkenen.

De technische scenario's zijn gepresenteerd in de bibliotheek van Almere voor een breder publiek. Ongeveer 50 mensen, veelal geïnteresseerden om land te kopen en te gaan wonen in Oosterwold en professionals van Wageningen University, de gemeente Almere en het Waterschap hebben de presentatie bijgewoond en gediscussieerd over milieu-technologische oplossingen voor Oosterwold.

Het ruimtelijk ontwerp is gepresenteerd bij het Amsterdam Institute for Advanced Metropolitan Solutions voor een breder publiek van voornamelijk Wageningse Landschapsarchitectuur studenten en hun begeleiders.
Voorwoord

Leeswijzer

Verdieping

Achtergrond

Colofon

Deze publicatie is het resultaat van he Wetenschapswinkelproject 'Circulair

Werelddorp Diamondiaal' uitgevoerd in opdracht van de Stichting Inspiratie Inc. 


\section{Colofon}

\section{Titel}

Auteur

Vormgeving

Circulaire werelddorp Diamondiaal Astrid Hendriksen

Wageningen University \& Research,

Communication Services

Beeld en fotografie De foto's, kaartjes en figuren zijn vervaardigd door de auteurs of de meewerkende studenten, tenzij anders aangegeven

\section{Circulair werelddorp Diamondiaal}

Wageningen University \& Research, april 2018

Wageningen University \& Research

Wetenschapswinkel rapport 341

ISBN: 978-94-6343-875-9

DOI: https://doi.org/10.18174/432341

Met medewerking van

ACT studenten groep: Alexander Boedijn, Anne Tjallingii, Anouk Stam, Carlotta Meriggi, Mona Regad

Atelier studenten groep: Ali Canning, Anne Johan Buis, Hossain Nahyan, Nienke van der Smissen, Petronella Magnusson

Thesis student: Judith Bosch

Capita selecta student: Xuan Chen

\section{Begeleidingscommissie}

Annet Kempenaar (Landschapsarchitect), Nora Sutton

(Milieutechnoloo, Rien de Ridder (Waterschap Zuiderzeeland), Tom Saal (Kunstenaar), Bas van Vliet (Milieubeleidsonderzoeker), Erik Heijmans (Advanced Metropolitan Solutions), Maria Jaartsveld (Advanced Metropolitan Solutions), Amal Abbass (Inspiratie Inc), Lèneke Pfeiffer (Coördinator Wetenschapswinkel), Astrid Hendriksen (projectleider)

Stichting Inspiratie Inc.: www.inspiratie-inc.n Stichting Inspiratie Inc. ontwikkelt creatieve vormen voor sociaal ondernemerschap, participatie en coöperatie, en de kracht van diversiteit. De stichting richt zich op iedereen, die een actieve plek in de samenleving zoekt: kinderen, jongeren, volwassenen en ouderen, met verschillende achtergronden, cultuur, religie, en sociale status. Het doel is om nieuwe vormen te vinden, waarin iedereen kan deelnemen en positief bijdraagt. Het gaat om het inspireren en activeren, om gezamenlijk plekken te creëren, die als een nieuw thuis voelen.
Amsterdam Institute for Advanced Metropolitan Solutions: www.ams-institute.org

AMS aims to become an internationally leading institute where talent is educated and engineers, designers, digital engineers and natural/social scientist jointly develop and valorize interdisciplinary metropolitan solutions. AMS is centered on applied technology in urban themes such as water, energy, waste, food, data and mobility, and the integration of these themes. AMS will develop a deep understanding of the city - sense the city - , design solutions sign solutions for its challenges, and integrate these into the city.

Wageningen University \& Research Master Programmes: Environmental Sciences, Urban Environmental Management \& Landscape Architecture and Planning.

www.wur.nl/en/Education-Programmes/master/MSc-programmes/ MSc-Environmental-Sciences.htm

www.wur.nl/en/Education-Programmes/master/MSc-programmes/ MSc-Urban-Environmental-Management.htm

www.wur.nl/en/Education-Programmes/master/MSc-programmes/ MSc-Landscape-Architecture-and-Planning.htm

Wageningen University \& Research, Wetenschapswinke Maatschappelijke organisaties zoals actiegroepen, stichtingen, verenigingen of belangengroepen kunnen met onderzoeksuragen verenig die een maatschappelijk doel dienen terecht bij de

Wetenschapswinkel van Wageningen University \& Research. Samen met studenten, onderzoekers en maatschappelijke groepen worden inspirerende onderzoeksprojecten mogelijk.

Onderzoeksvragen moeten aanslulten bij de Wageningen

University Lifesciences thema's: duurzame landbouw, voeding \& gezondheid, een leefbare groene ruimte en maatschappelijke veranderingsprocessen.

\section{Copyright}

(c) 2018 Wageningen University \& Research

Verspreiding van het rapport en overname van gedeelten eruit worden aangemoedigd, mits voorzien van deugdelijke

bronvermelding.

\section{Aansprakelijkheid}

Wageningen University \& Research aanvaardt geen

aansprakelijkheid voor eventuele schade voortvloeiend uit het

gebruik van de resultaten van dit onderzoek of de toepassing van de adviezen.
Voorwoord

Leeswijzer

Verdieping

Achtergrond

Colofon 

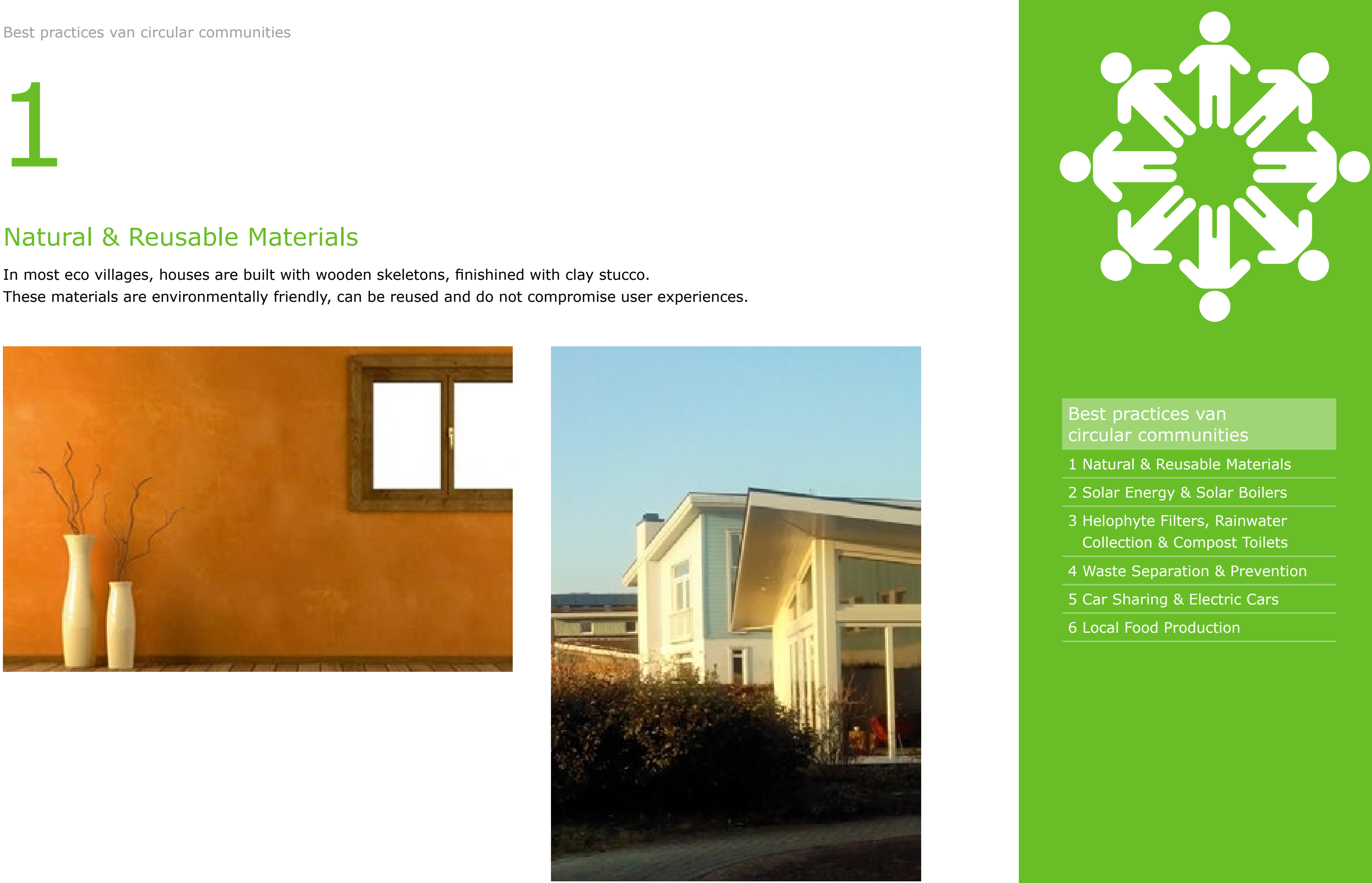

Best practices van

circular communities

1 Natural \& Reusable Materials

2 Solar Energy \& Solar Boilers

3 Helophyte Filters, Rainwater

Collection \& Compost Toilets

4 Waste Separation \& Prevention

5 Car Sharing \& Electric Cars

6 Local Food Production 


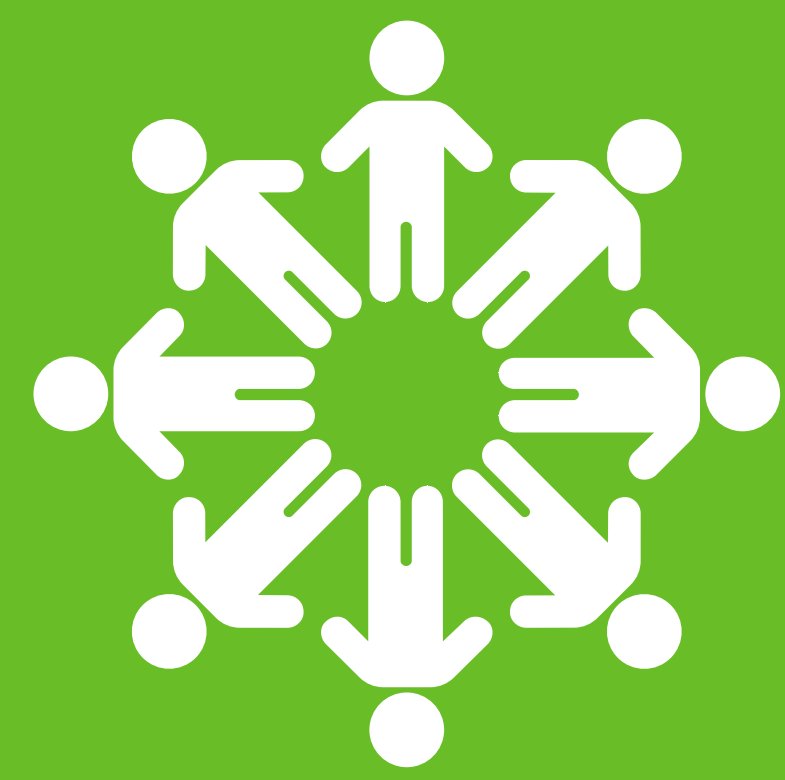
preheat tap and central heating water. These renewable energy sources function well according to eco village residents. Solar boilers require some maintenance every few years.
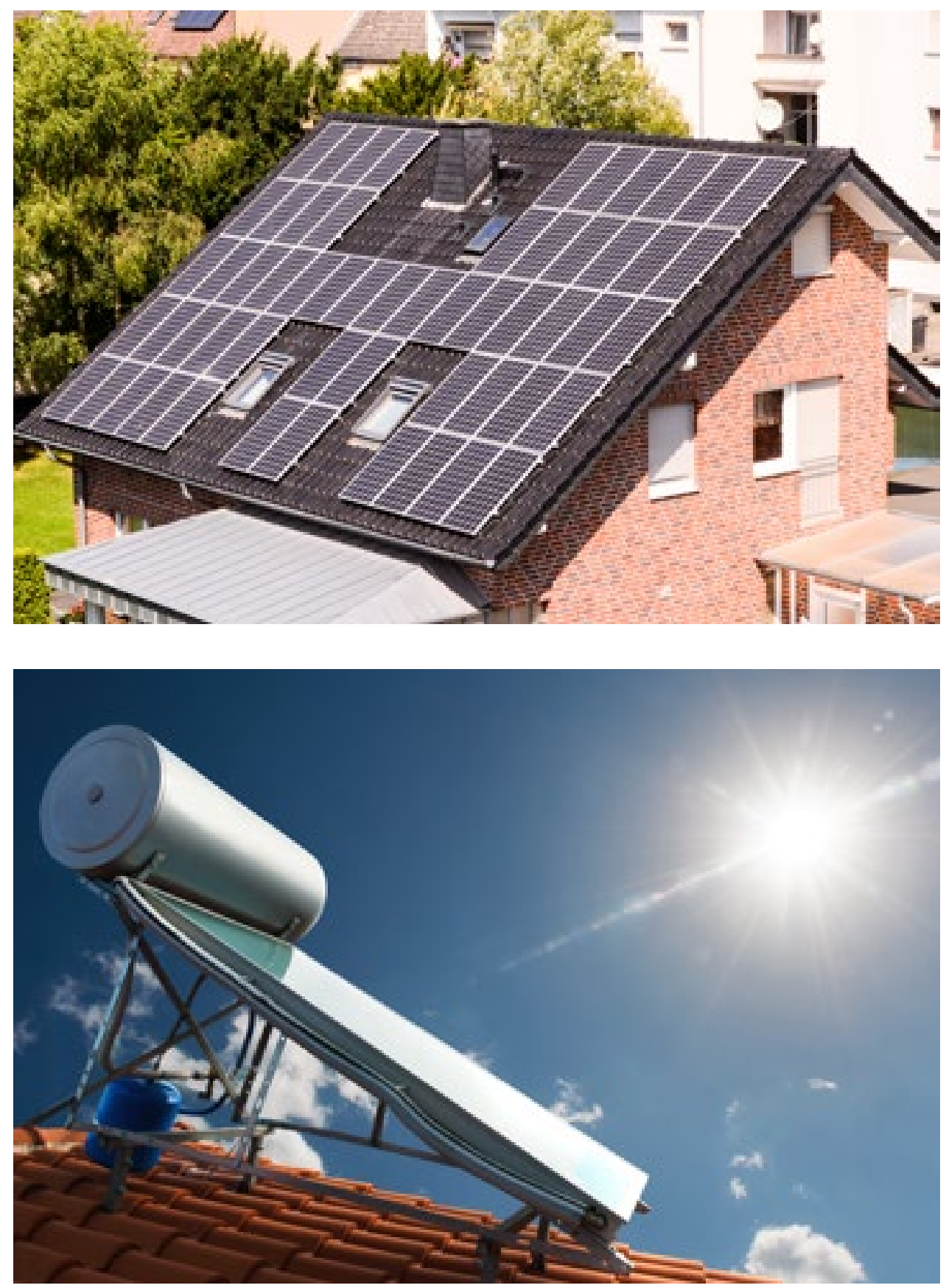

Best practices van

circular communities

1 Natural \& Reusable Materials

2 Solar Energy \& Solar Boilers

3 Helophyte Filters, Rainwater Collection \& Compost Toilets

4 Waste Separation \& Prevention 5 Car Sharing \& Electric Cars

6 Local Food Production 


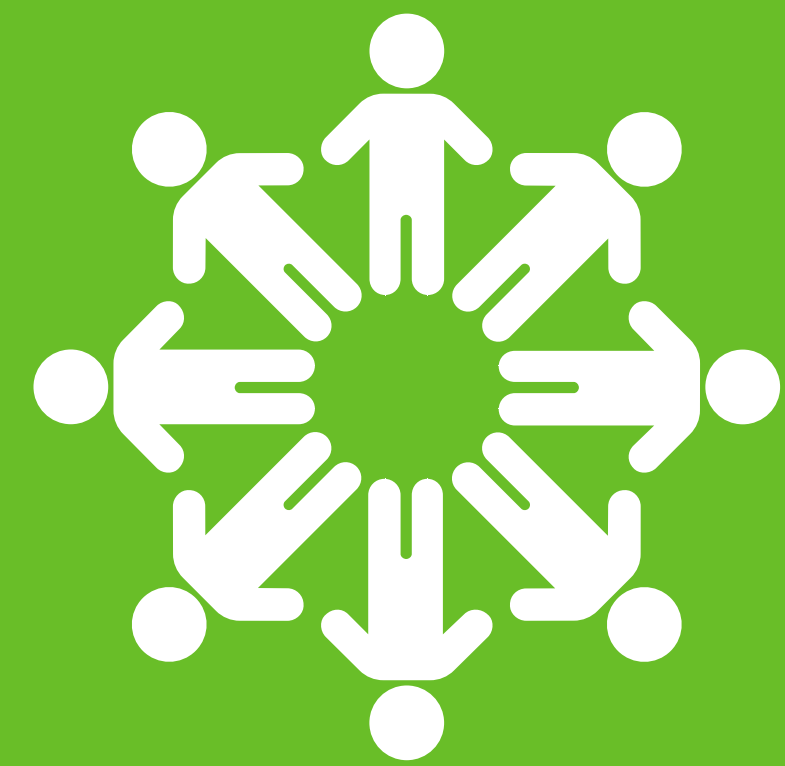

Waste water is cleaned through helophyte filter. These solutions function well. Groene Dak experimented with a compost toilet, but composting did not occur naturally, forcing people to stir their own excrements and leading to a accumulation of ammonia, and finally the compost toilets had to be removed.

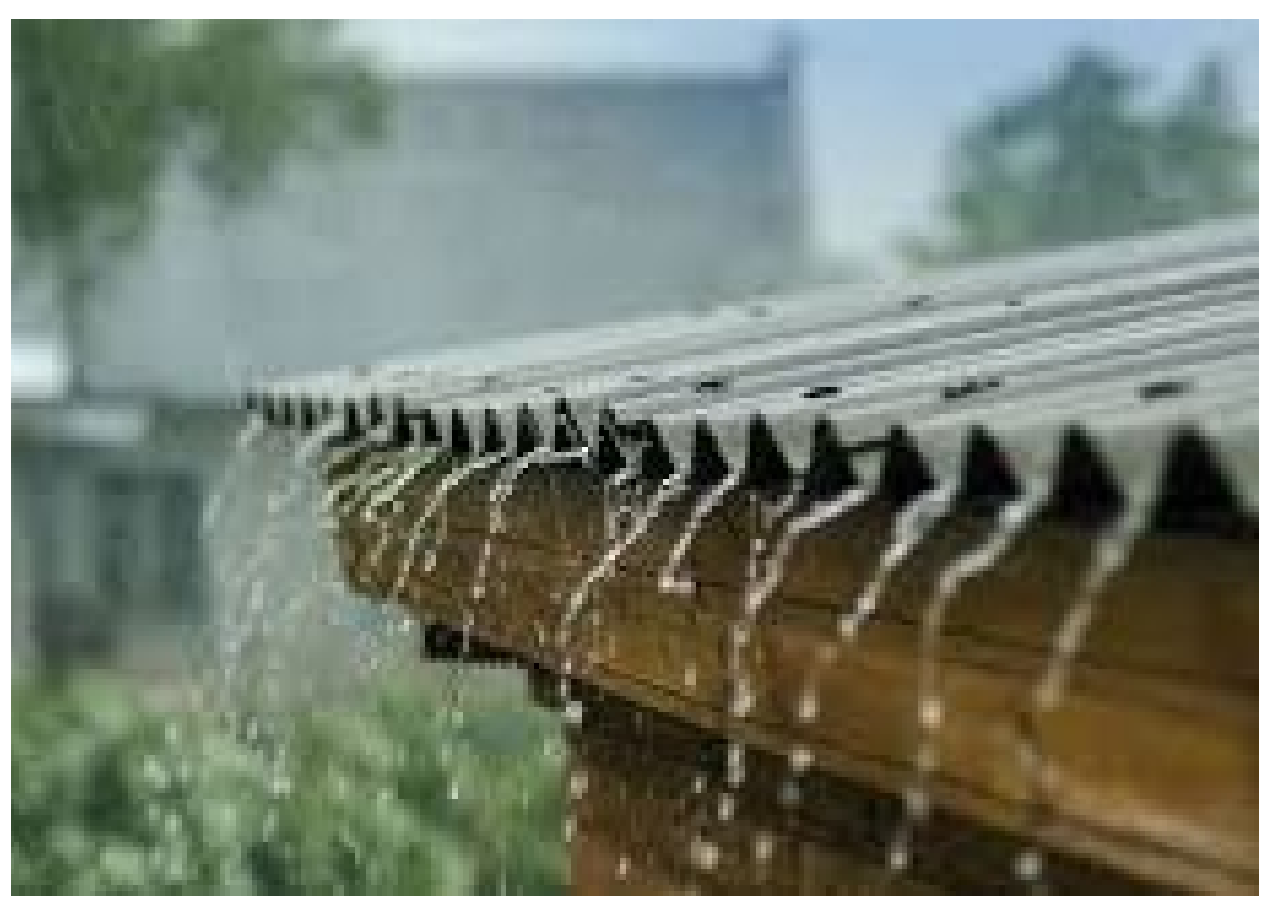

Best practices van

1 Natural \& Reusable Materials

2 Solar Energy \& Solar Boilers

3 Helophyte Filters, Rainwater Collection \& Compost Toilets

4 Waste Separation \& Prevention

5 Car Sharing \& Electric Cars

6 Local Food Production circular communities

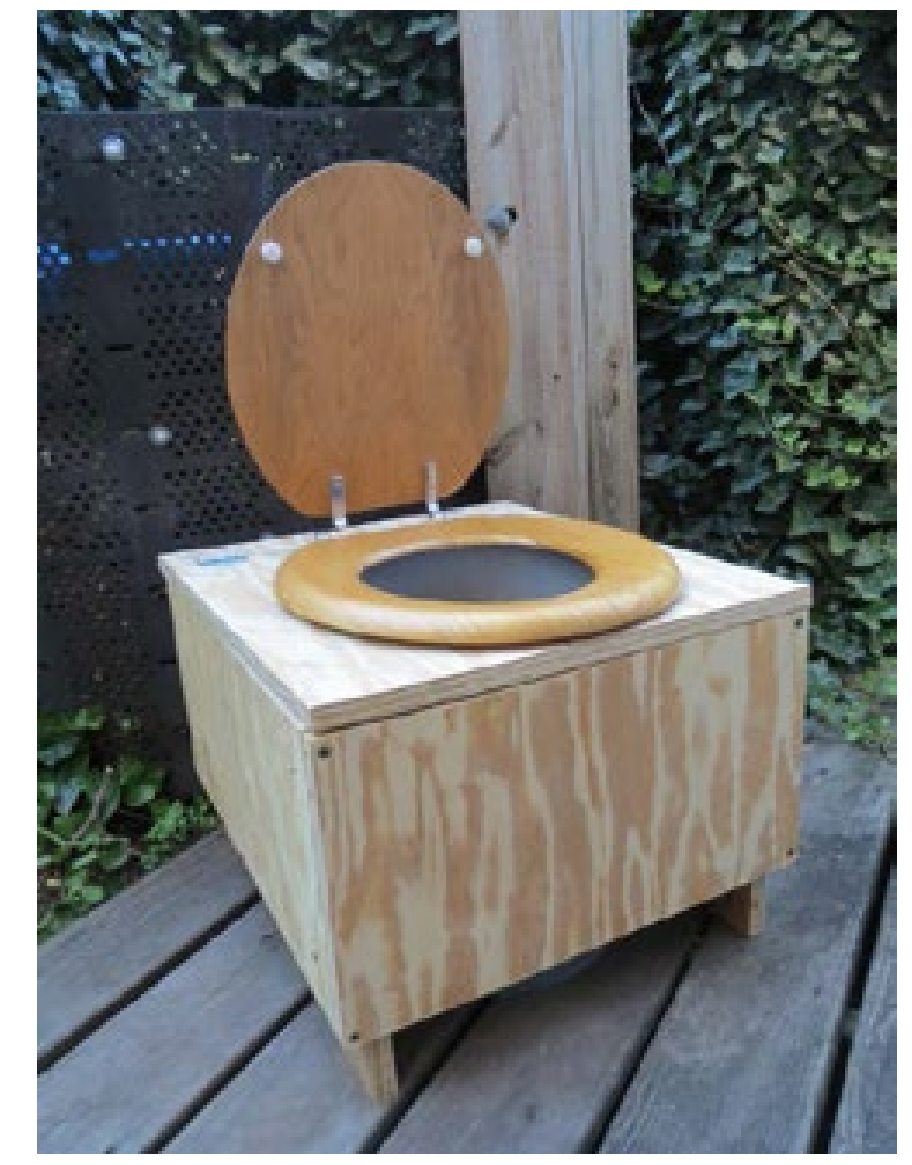



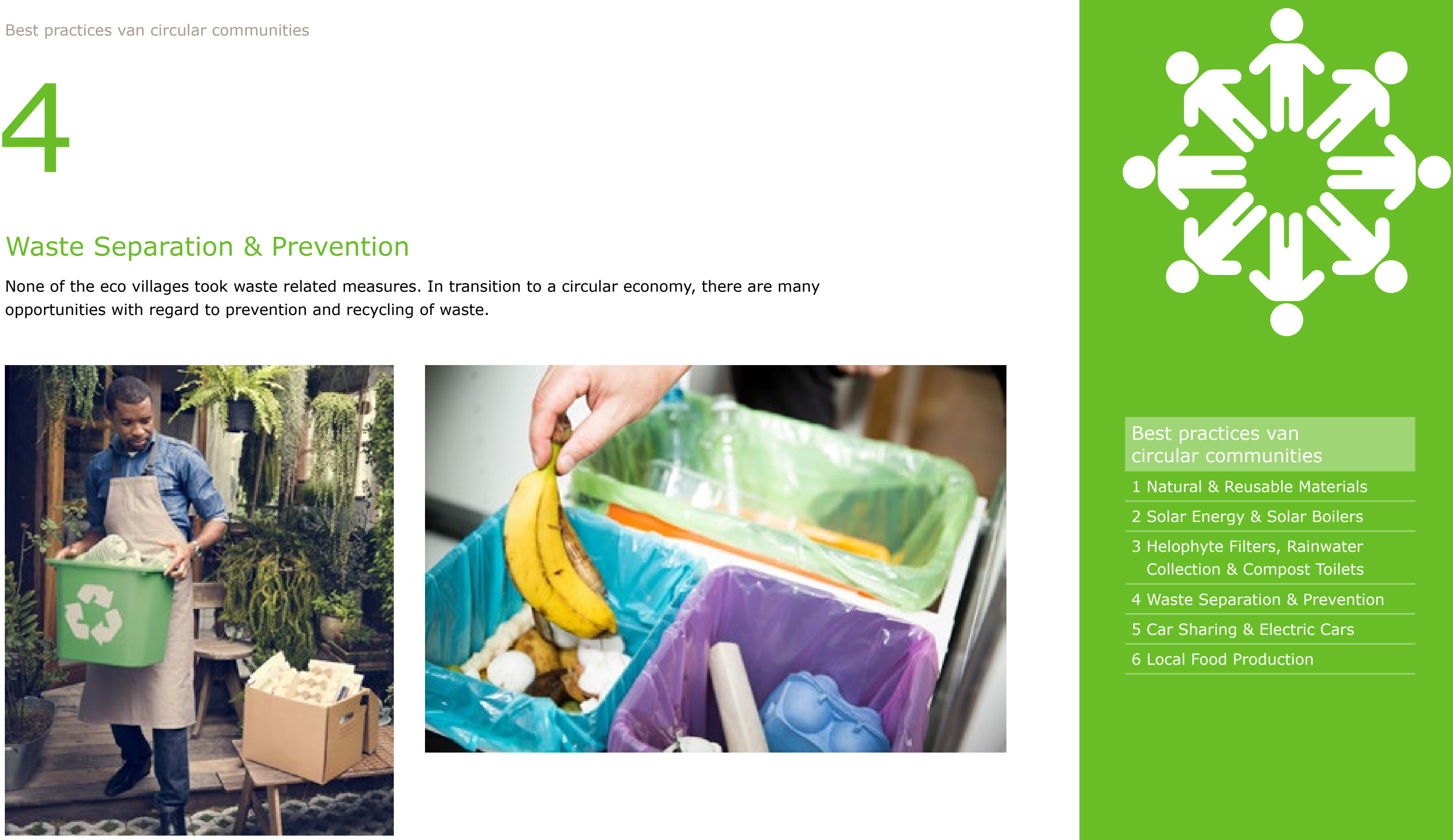

Best practices van

circular communities

1 Natural \& Reusable Materials

2 Solar Energy \& Solar Boilers

3 Helophyte Filters, Rainwater Collection \& Compost Toilets

4 Waste Separation \& Prevention

5 Car Sharing \& Electric Cars

6 Local Food Production 


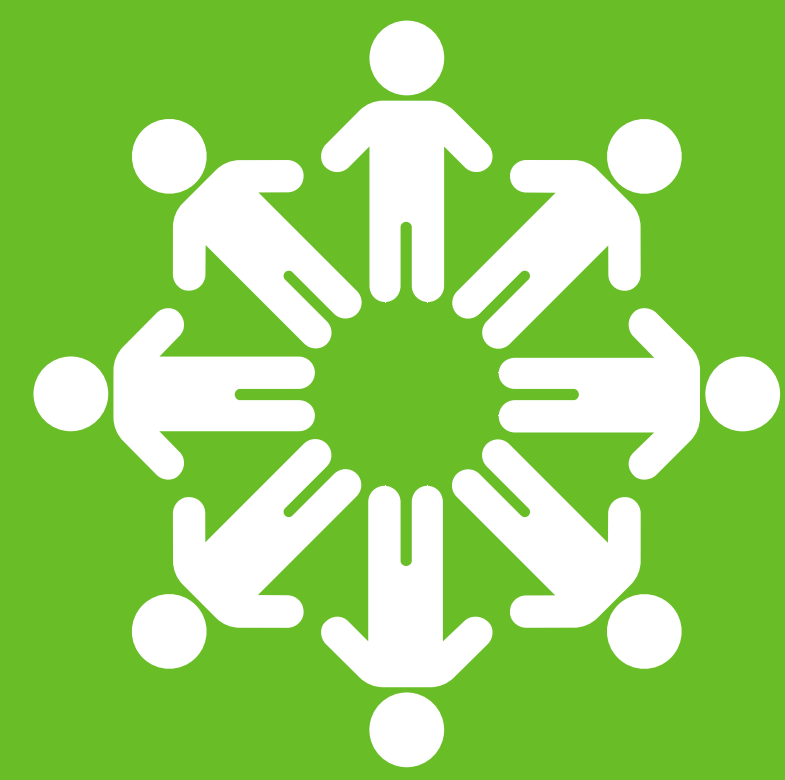
a car in de neighbourhood, to facilitate car sharing and discourage buying cars.

\section{Car Sharing \& Electric Cars}

Meanderhof installed an eclectric car charging pole that runs on solar power and has arranged for Greenwheels to place

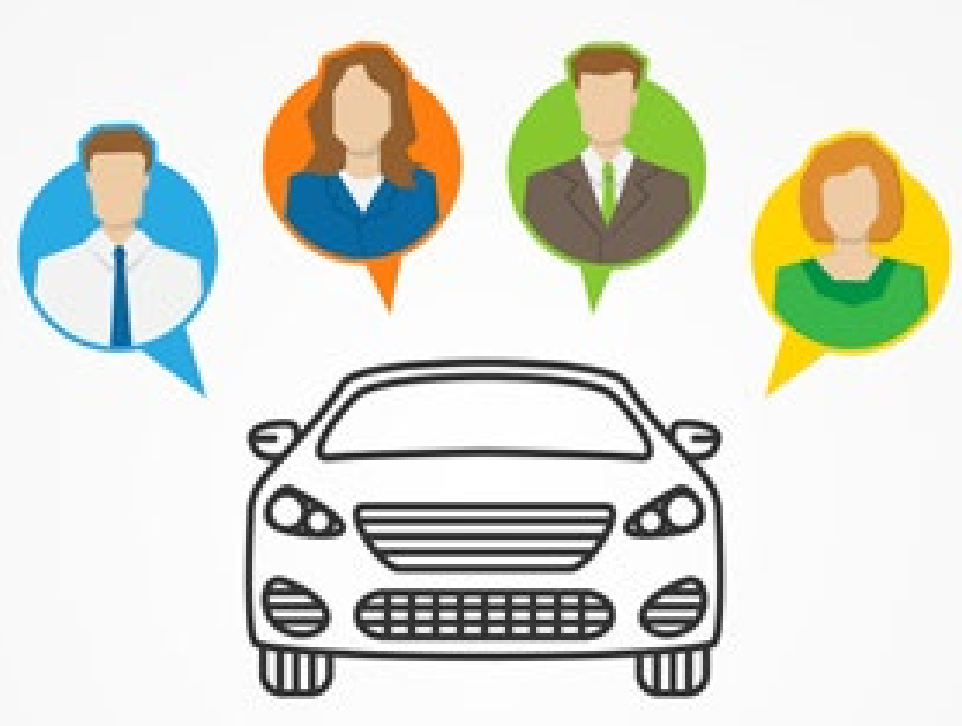

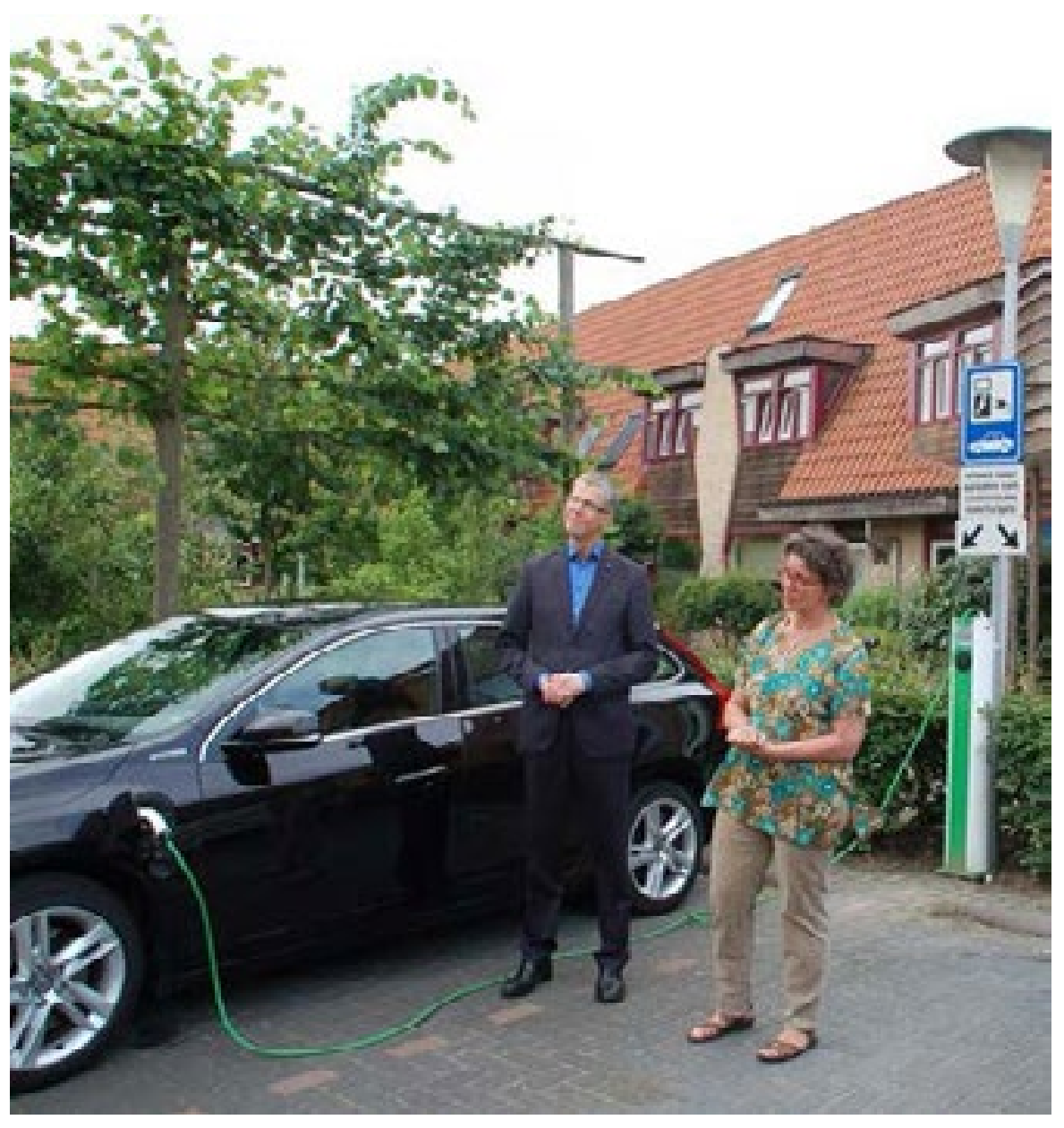

Best practices van

circular communities

1 Natural \& Reusable Materials

2 Solar Energy \& Solar Boilers

3 Helophyte Filters, Rainwater Collection \& Compost Toilets

4 Waste Separation \& Prevention

5 Car Sharing \& Electric Cars

6 Local Food Production 


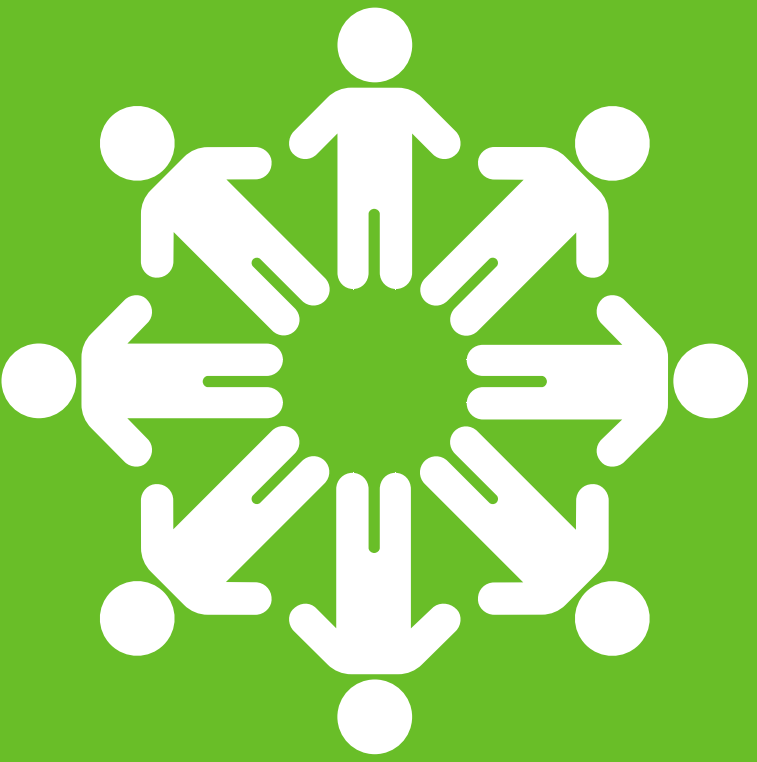

gardens, that mostly fulfill recreational purposes EVA-Lanxmeer built an urban farm, that provides the neighbourhood with food. It includes a shop and functions as a Care Farm. If an eco village lacks the facilities to locally produce food, joining a local food scheme or a community supported agriculture farm is an option.
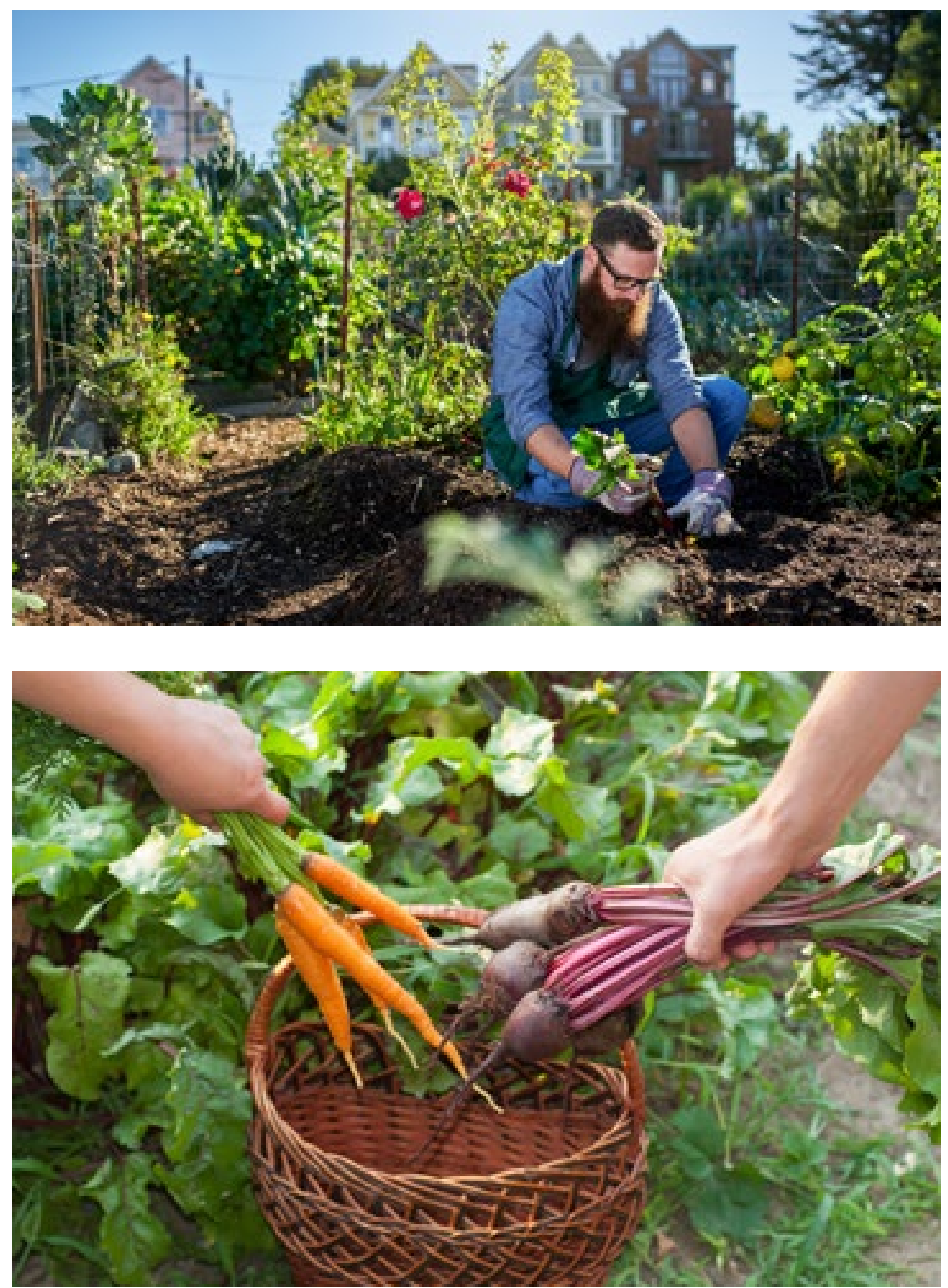

Best practices van

circular communities

1 Natural \& Reusable Materials

2 Solar Energy \& Solar Boilers

3 Helophyte Filters, Rainwater Collection \& Compost Toilets

4 Waste Separation \& Prevention

5 Car Sharing \& Electric Cars

6 Local Food Production 


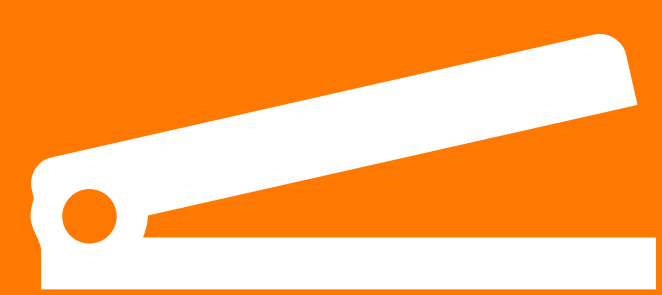

\section{Make it ours}

An external organization invests in the planning and development of a sustainable community. Important investments for a large-scale infrastructure. To supply sufficient energy, water and produce food for the whole community, systems are centralized and resort to advanced technologies implemented and monitored by outsourced specialists. Inhabitants benefit from the technologies and are represented at the community level by a mixed board of residents and representatives of the institution in charge of the design and management.

\section{Themes}

- Centralized

- Community level

- Low citizen involvement

- Top-down decision-making

- Indirect implementation

\section{Concept}
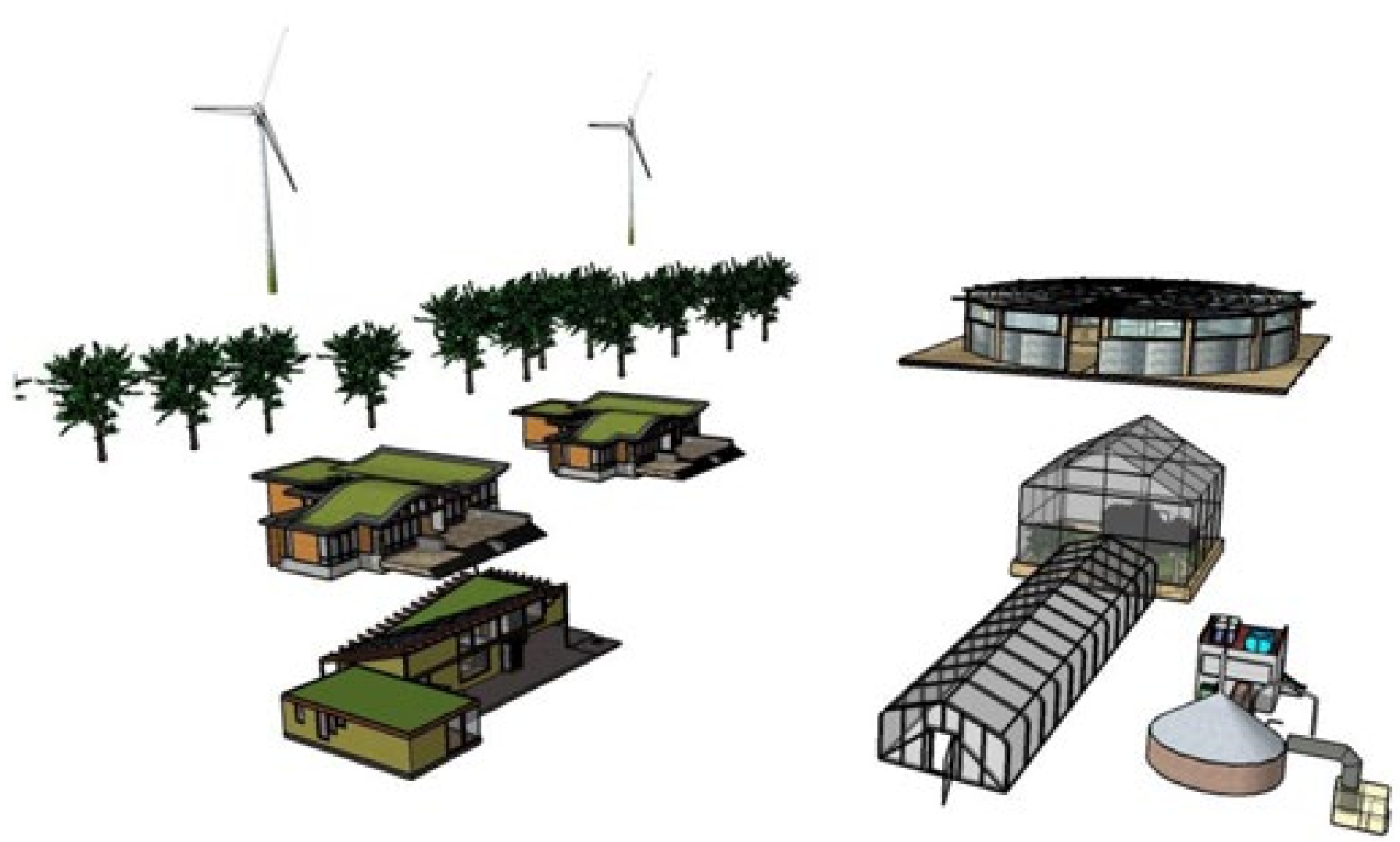

Technische scenario's

1 Make it ours

2 Do it yourself

3 Make it Mine

4 Do it together 


\section{Systems}
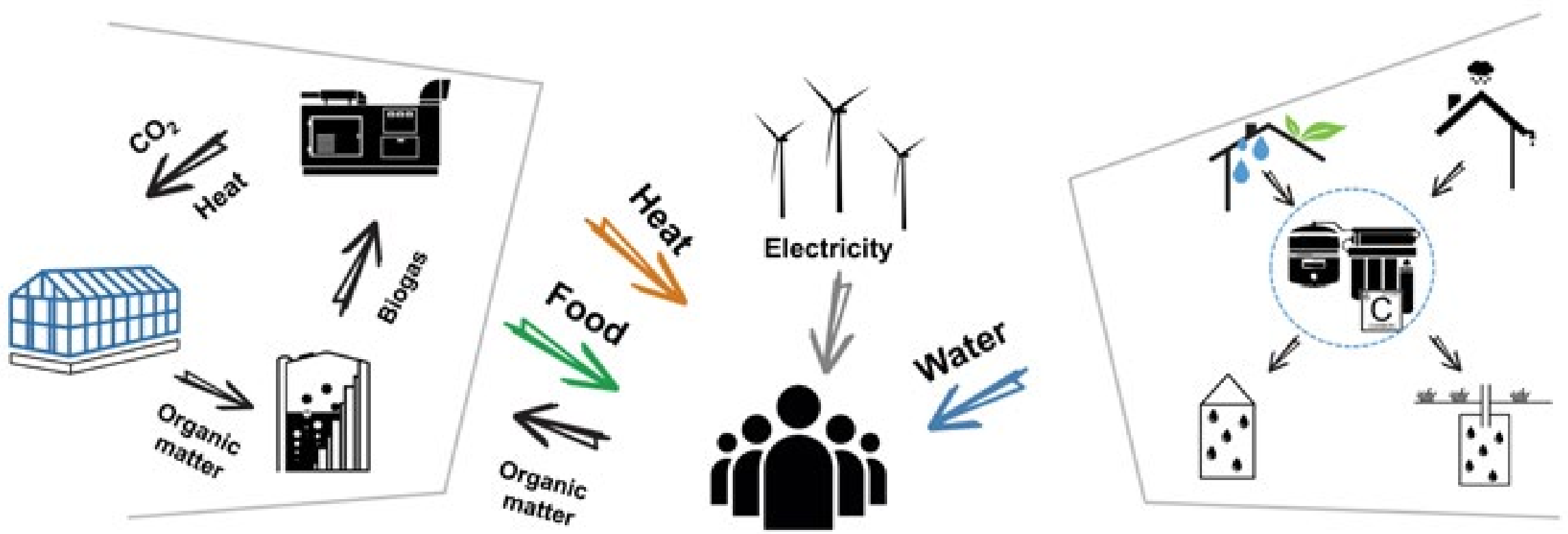

\section{Advantages}

- Off-the-grid

Completely self-sufficient and off-the-grid due to large scale and high-tech solutions.

- Long lasting

High reliability on the efficiency of large-scale technologies.

- Shared

Technologies are shared with all people.

\section{Disadvantages}

- Low citizen engagement

Technologies are already there: Low citizen

involvement in the decision-making process.

- High costs

- Dependency

High-tech solutions on a large scale require

professional help and expertise

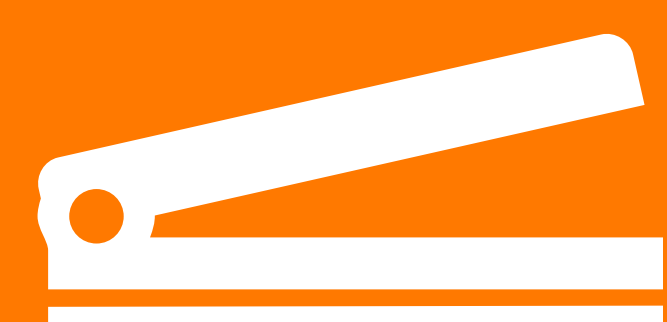

\section{8}

Technische scenario's

1 Make it ours

2 Do it yourself

3 Make it Mine

4 Do it together 


\section{Do it yourself}

You have this idea of your sustainable dream house, and you are going to build it yourself. At the scale of your own home, you select technologies to make it as circular as possible. Unless you decrease significantly your demands, or have strong skills in food production for example, you will need resources outside of your system and from the grid. However, within your house, you can select any technology you would like and experiment with some combinations. Your home is unique and will look like nothing else!

\section{Themes}

- Diversity

- Household level

- High citizen involvement

- Direct decision-making

- Direct implementation

\section{Concept}

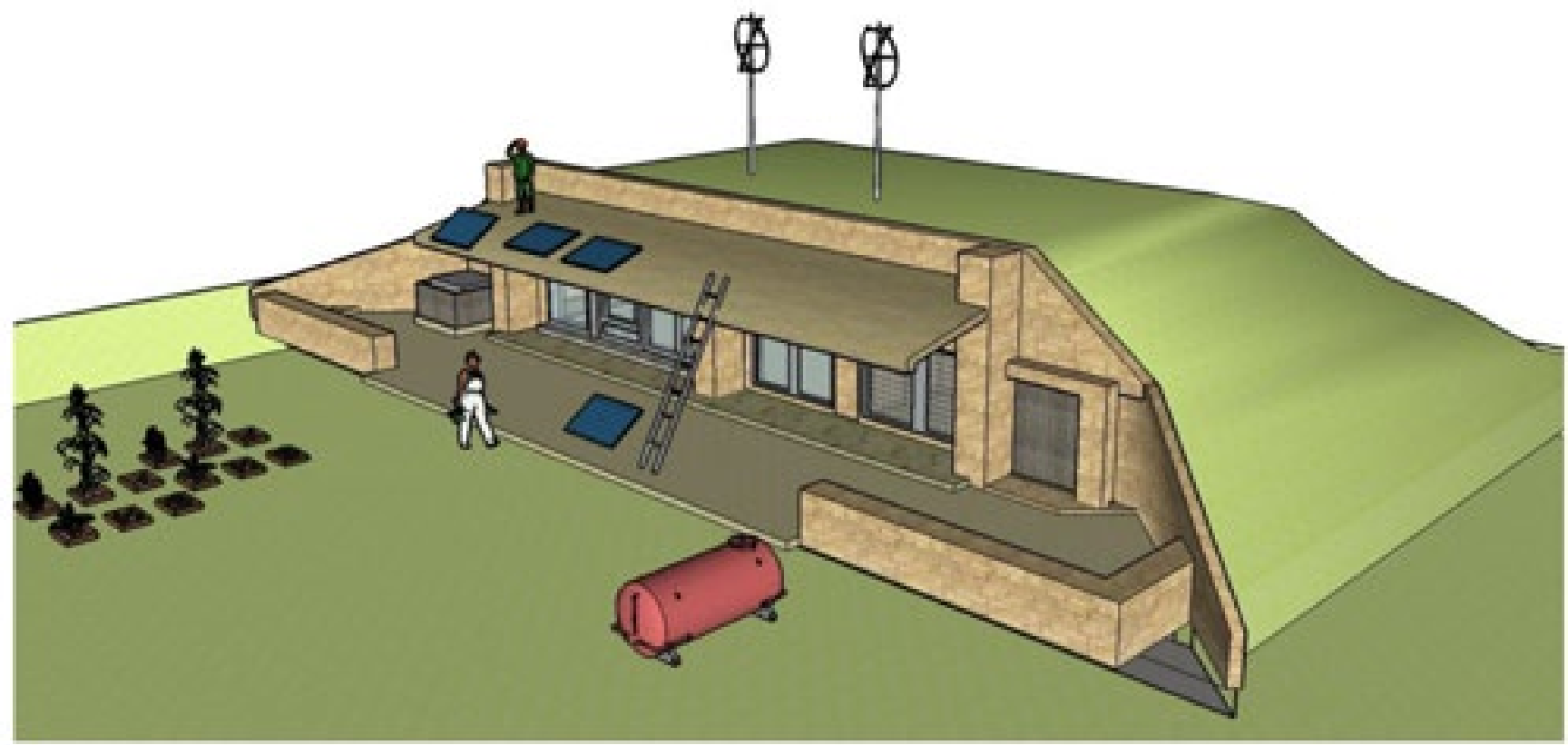




\section{Systems}
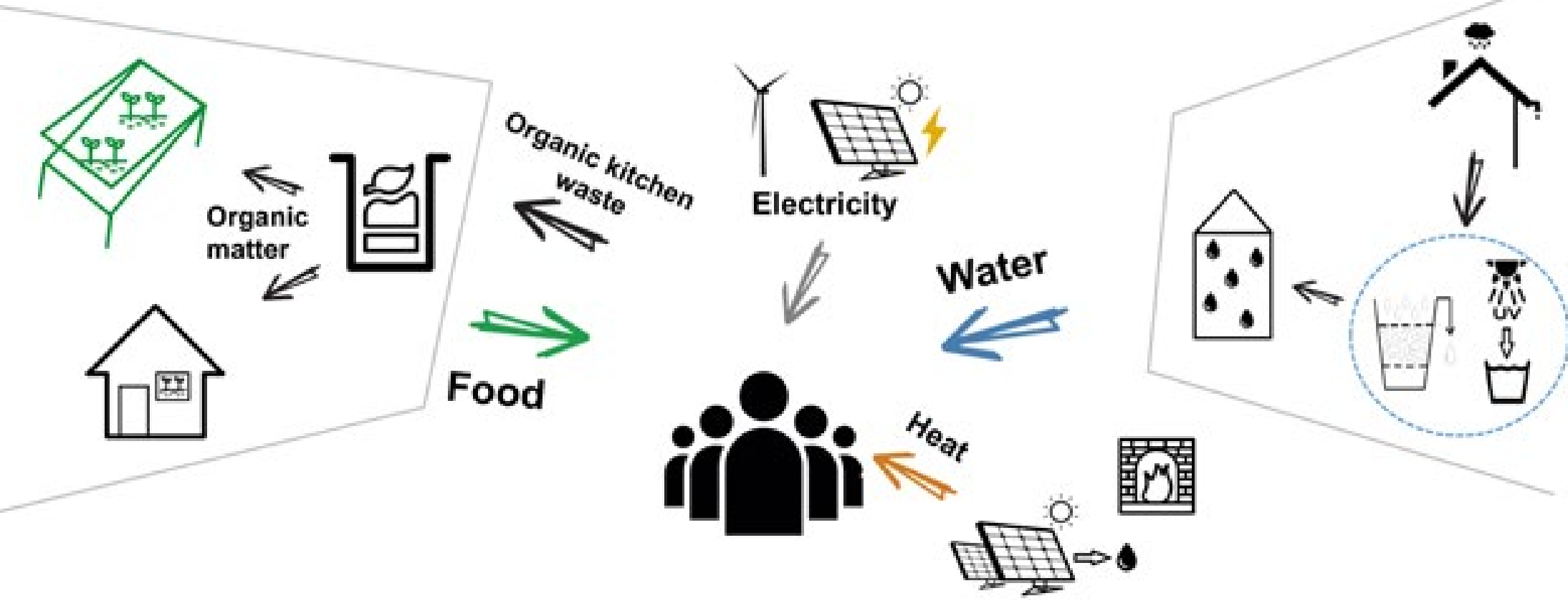

\section{Advantages}

- Process involvement

High individual involvement due to DIY technologies.

- Low costs

\section{Disadvantages}

- Not off-the-grid

Not completely self-sufficient and not off the grid, due

to small scale and low-tech solutions.

- Less circular

Low production of energy, water and food, due to small scale and low technologies.
Technische scenario's

1 Make it ours

2 Do it yourself

3 Make it Mine

4 Do it together 


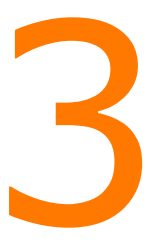

\section{Make it mine}

Organic matter Ready to move into a home tailored to your needs and demands? Involved throughout the planning process, you pick the design of your household yourself among existing solutions chosen for you by experts. Your home will function in isolation from others through tested and proven technologies at the household level. The circularity of your home will depend on your own demands for energy, water and food production. You state your needs and intentions, and let specialists create and build this system for you.

\section{Concept}

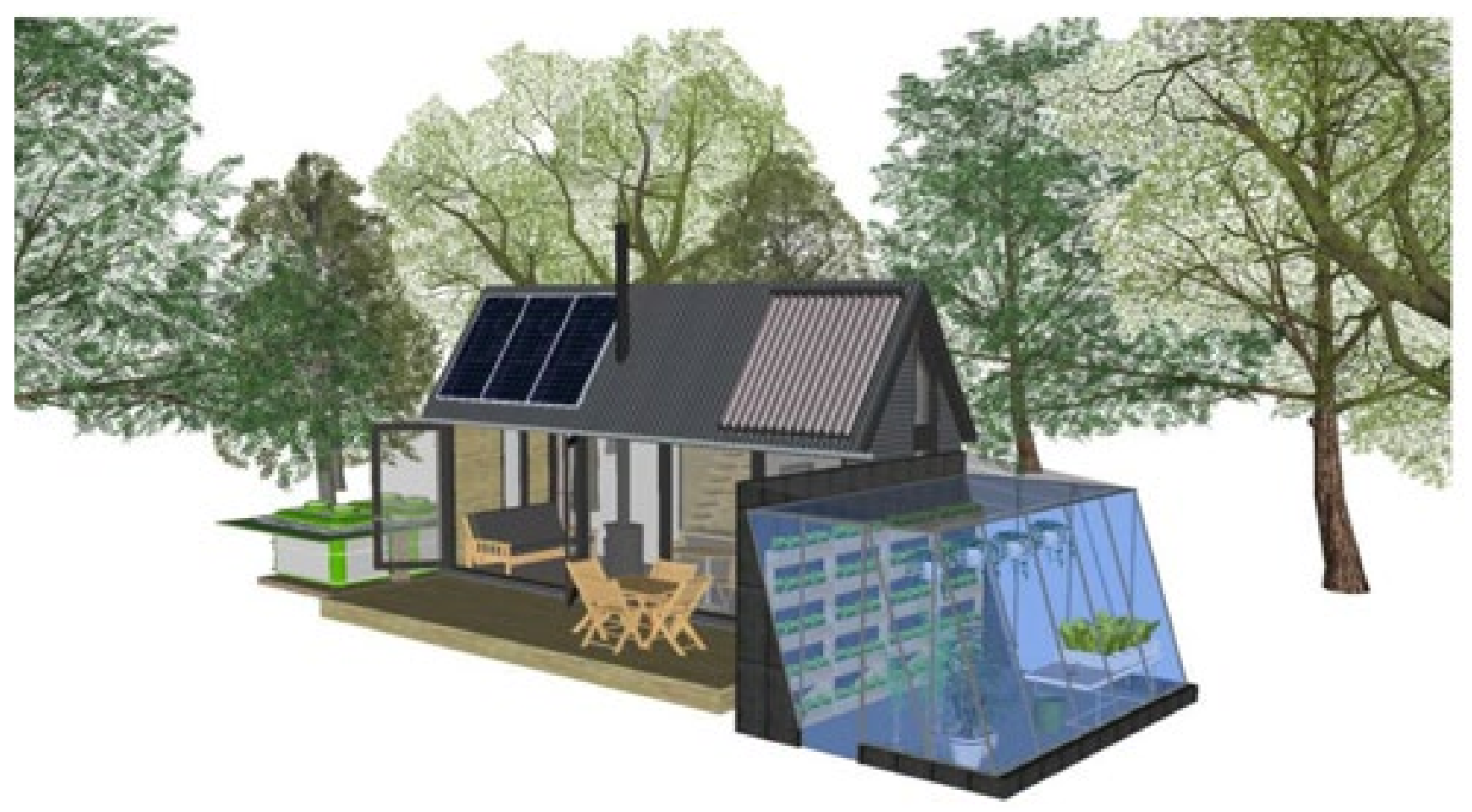

\section{Themes}

- Standardized

- Household level

- Medium involvement

- Direct decision-making

- Indirect implementation
Technische scenario's

1 Make it ours

2 Do it yourself

3 Make it Mine

4 Do it together

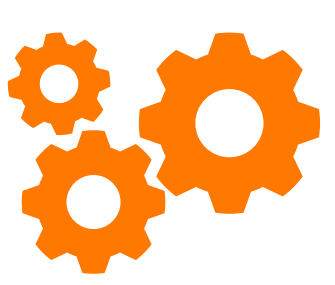



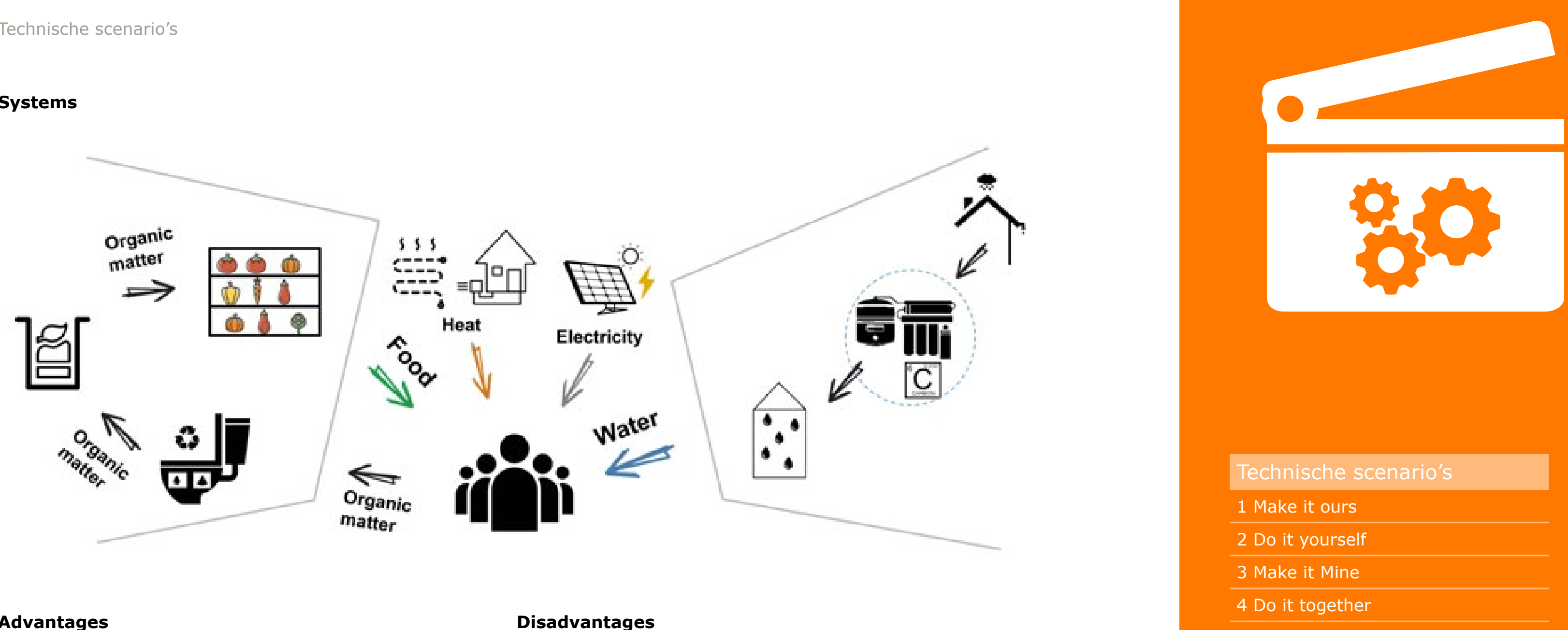

\section{Advantages}

\section{Disadvantages}

Complementation

All technologies complement each other.

- Assortment

Citizens select their housing from an assortment of possible housing options.

- Certainty

There is the reliabilty of tested and proven technologies.

- Standardized

All houses are pre-fabricated.

- Low citizen engagement

Houses and technologies are already there: low

involvement of the citizens in the implementation process.

- Dependency

Professional help is required for the building process and maintenance. 


\section{Do it together}

Electricity Heat The community organizes itself to develop and manage a space for living. Its main characteristic consists of the design and construction done by the people themselves. Everyone contributes to it with his own time and expertise. Technologies for supplying the village with energy, water and food are selected and voted on by the people. This creates

homogeneity throughout the buildings. An elected board

of representatives is in charge of establishing and

enforcing the rules to ensure proper functioning of the project.

\section{Themes}

- Centralized

- Community level

- Medium citizen involvement

- Direct implementation

- Bottom-up decision-making

Concept
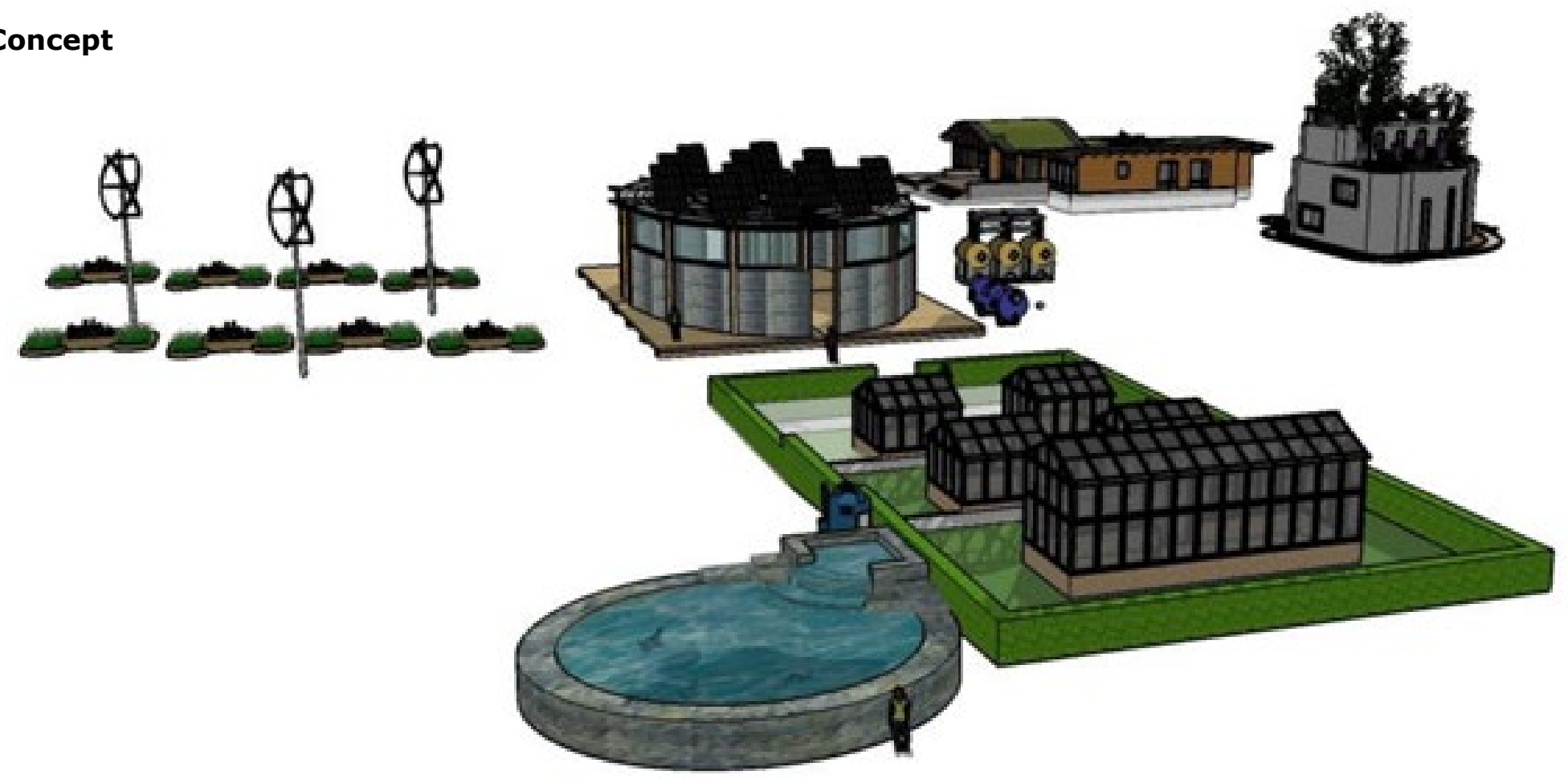

Technische scenario's

1 Make it ours

2 Do it yourself

3 Make it Mine

4 Do it together 


\section{Systems}

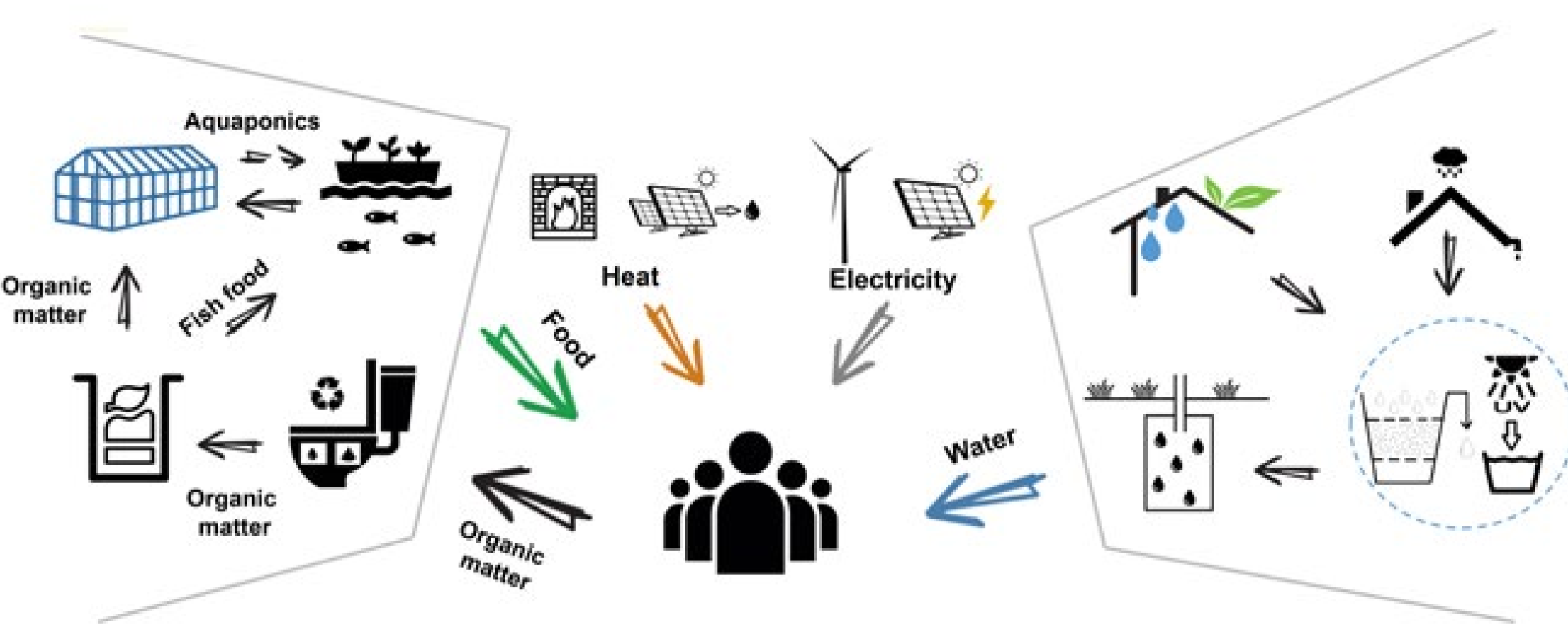

\section{8}

Technische scenario's

\section{Advantages}

- Shared

Technologies are shared with all inhabitants.

- High solidarity

Citizens will work together to find solutions and to build the community.

- High citizen engagement

Community governance by citizens themselves.

\section{Disadvantages}

- Dependency

Knowledge and expertise within the community need

to be sufficient to implement the technologies.

- Off-the-grid?

Uncertainties on the circularity of the technologies and actual level of self-sufficiency.

- Regulations

Necessity to abide by the rules defined by the

community. 

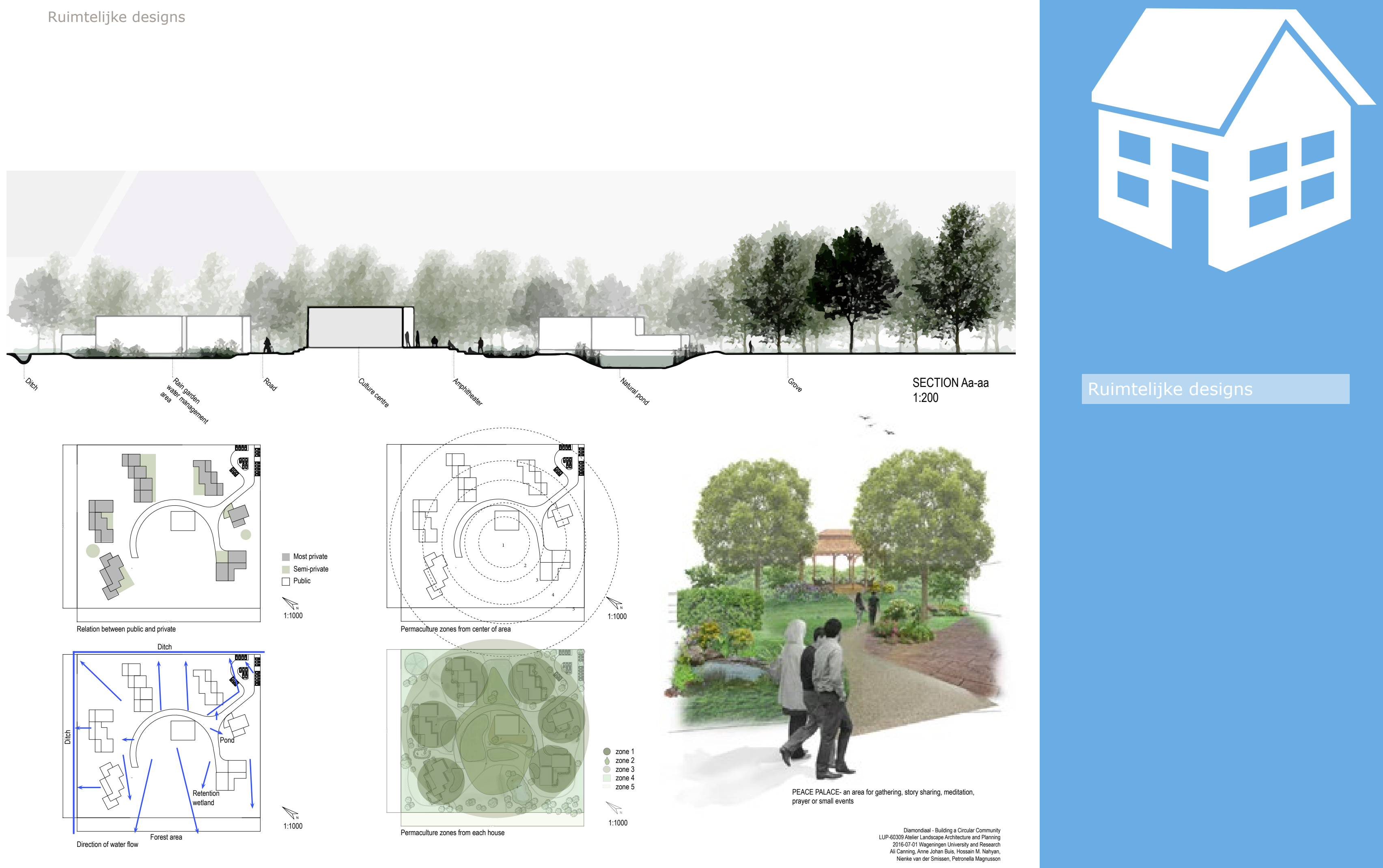

Ruimtelijke designs 

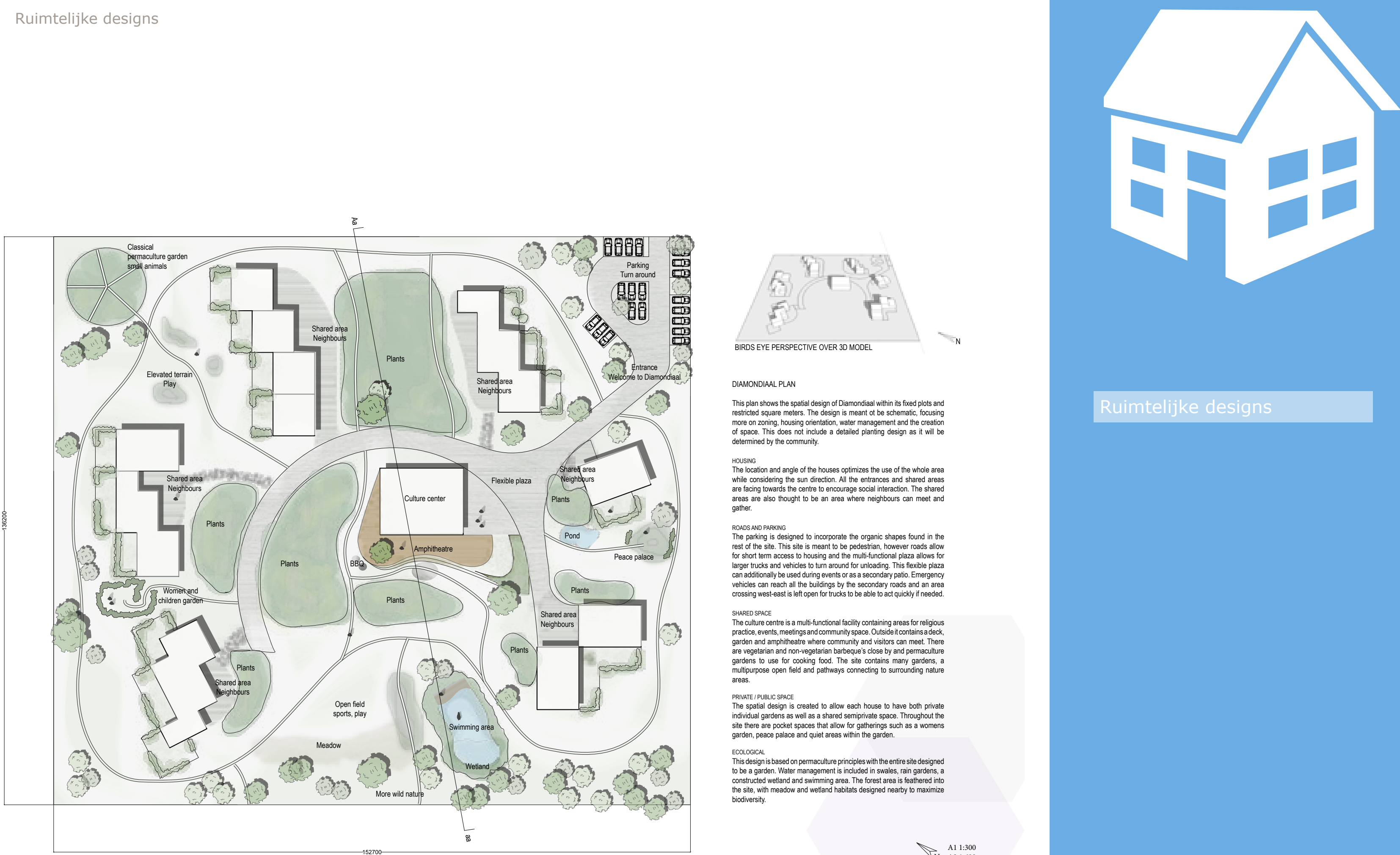

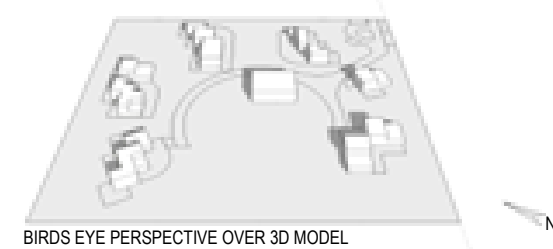

BIPDS EYE PERSPCCTVE OVER J MOOEL

DIAMONDIAAL PLAN

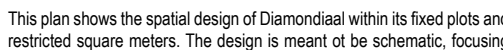

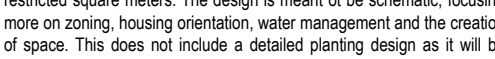

Housmo
The location and angle ef the houses opinizizes the use of the whole aree

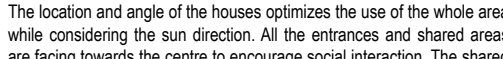

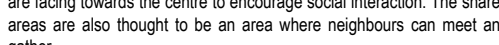

ROAOS AND PARKN
The parking is desinged to incorporate the organic shapes found in the

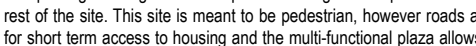

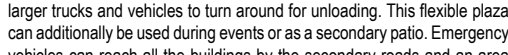

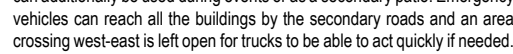

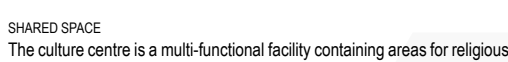

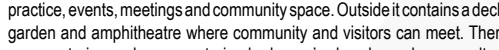

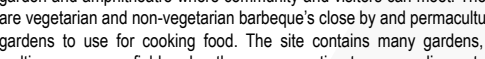
Mutipurpose open
areas.

PRVATEE PUUBLC SPACE

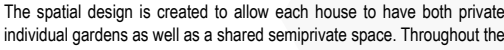
site there are pocket spaces that allow for gatherings such as a womes

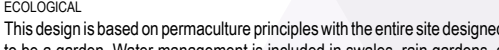

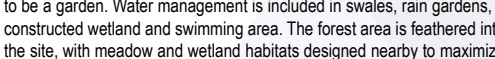
thes
biodite wistity 
.

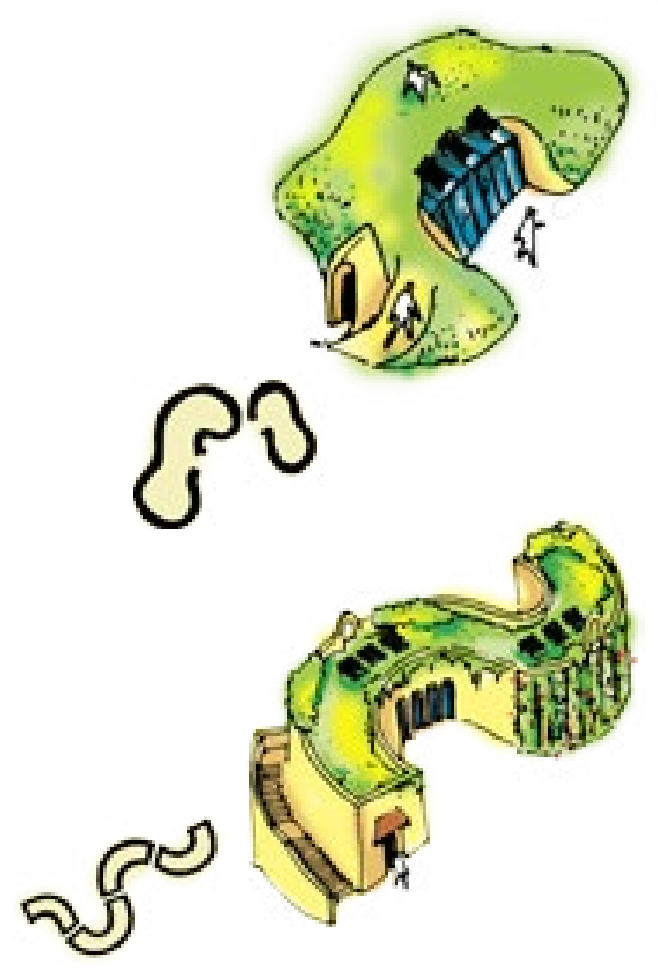

-Form articulated in organic shapes

-The thick earth wall acts as themal mass
- -The north elevation is designed with glazed opening
The south openings are desinged to allow winter and summer sun inside The roof is is ighy insulated to prevent tuwwanted heat admititance .

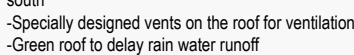

- Treen roof to delay rain water runofi
-The slope of the roof can be designed to be wakable but requires much

space
-Unique nature of the shapes prefabicicated constructions

CURVILNEAR HOUSES:

-Only the plan is sarticulated in organic shapes
-The curvature of the vertical walls offers more surface aree

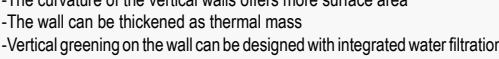

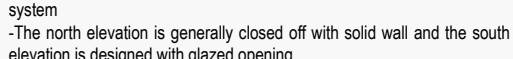

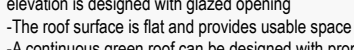

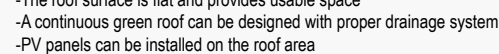

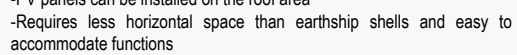

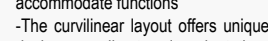

design according to solar rienentition
-Prefaboricated construction is possible
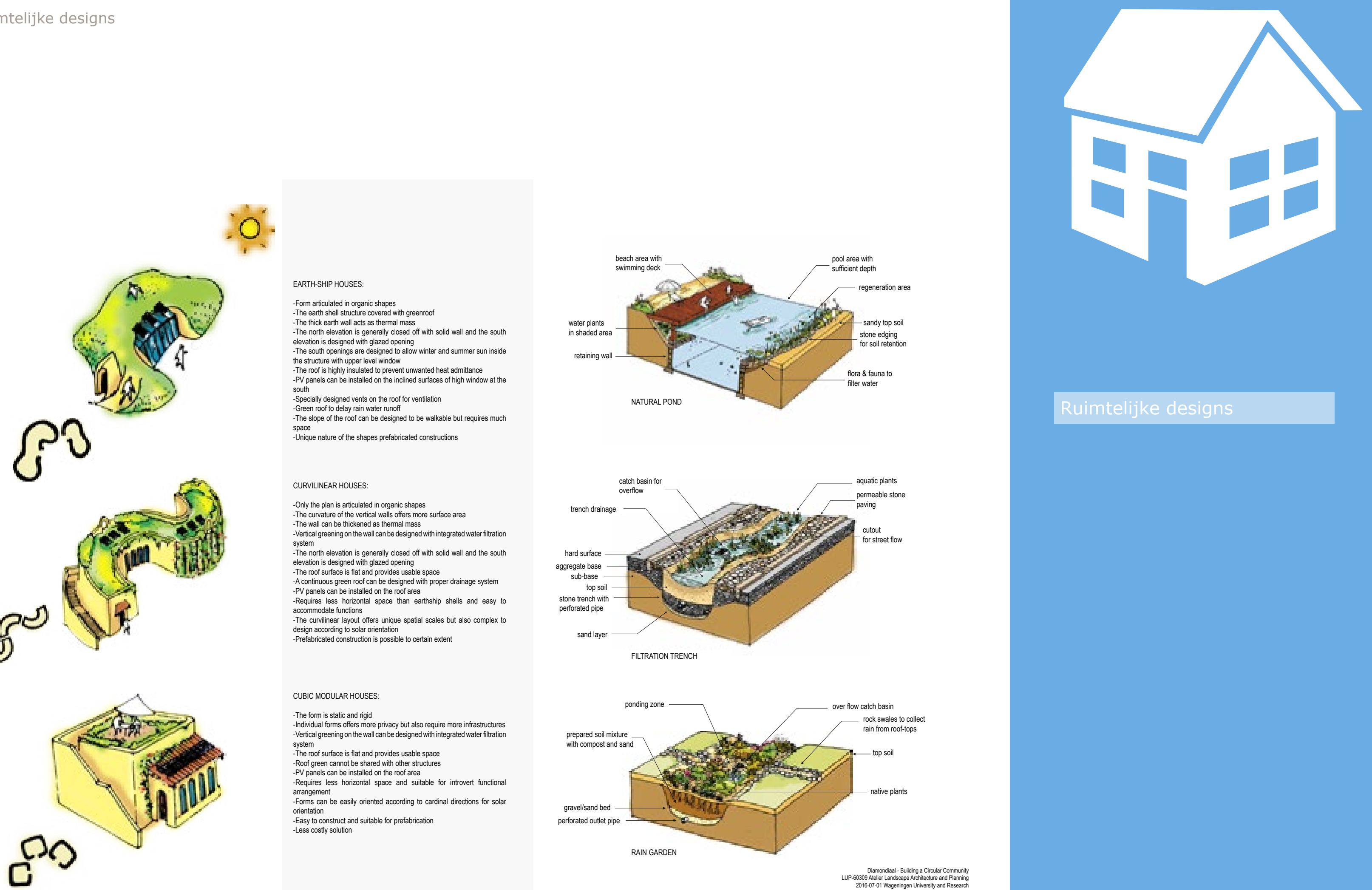

CUBIC MODULAR HOUSES:

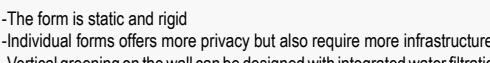
system

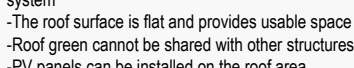
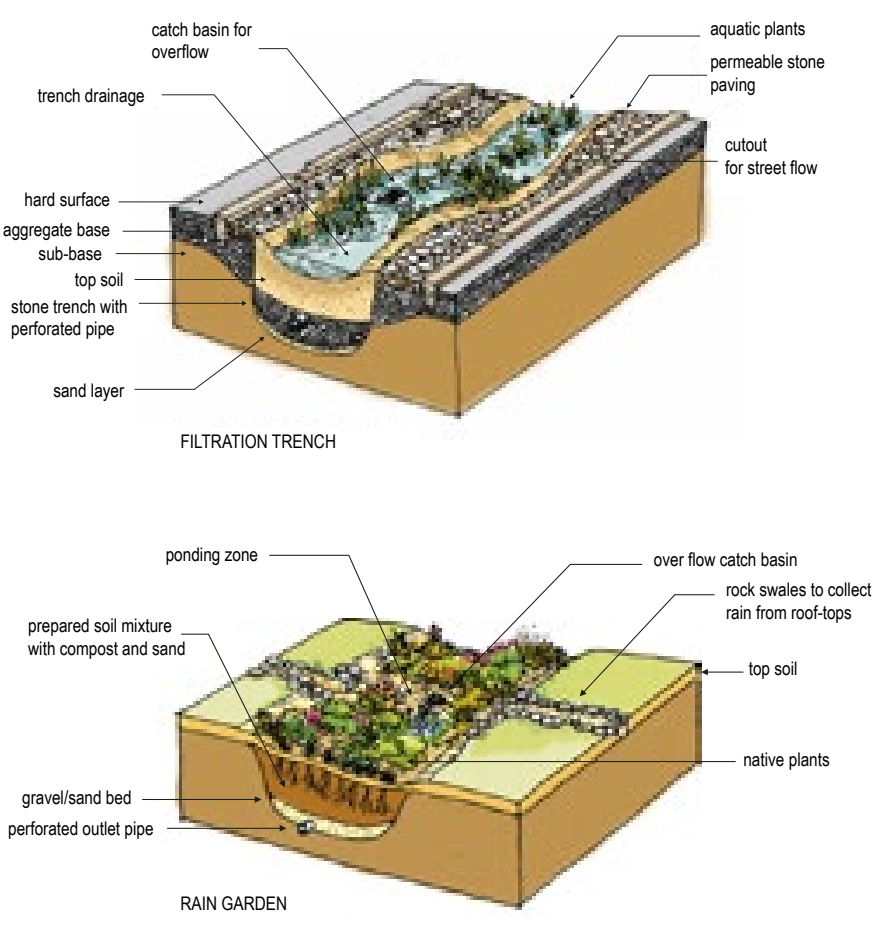

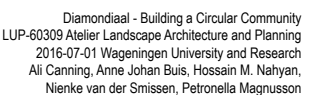

Ruimtelijke designs 

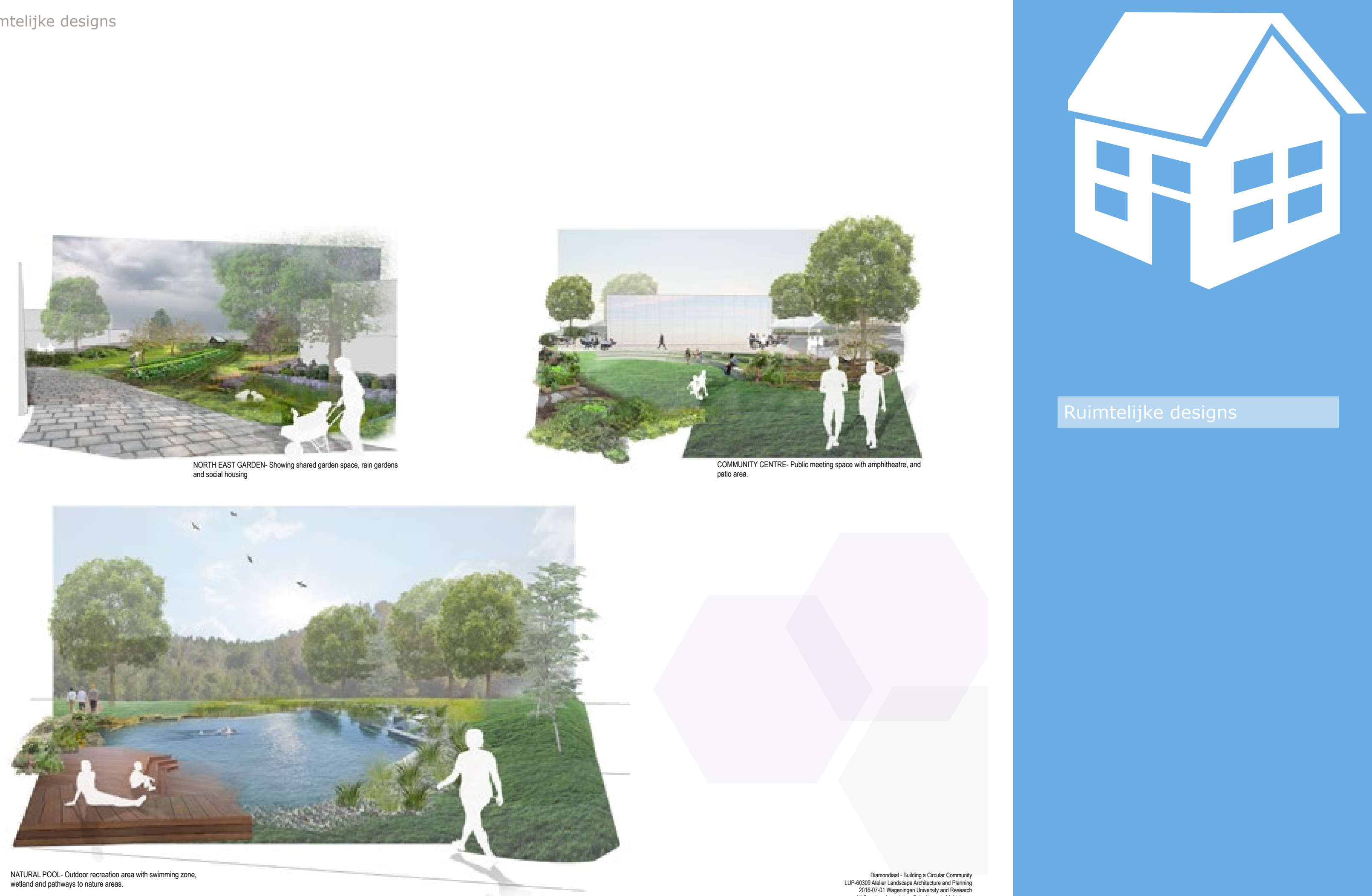

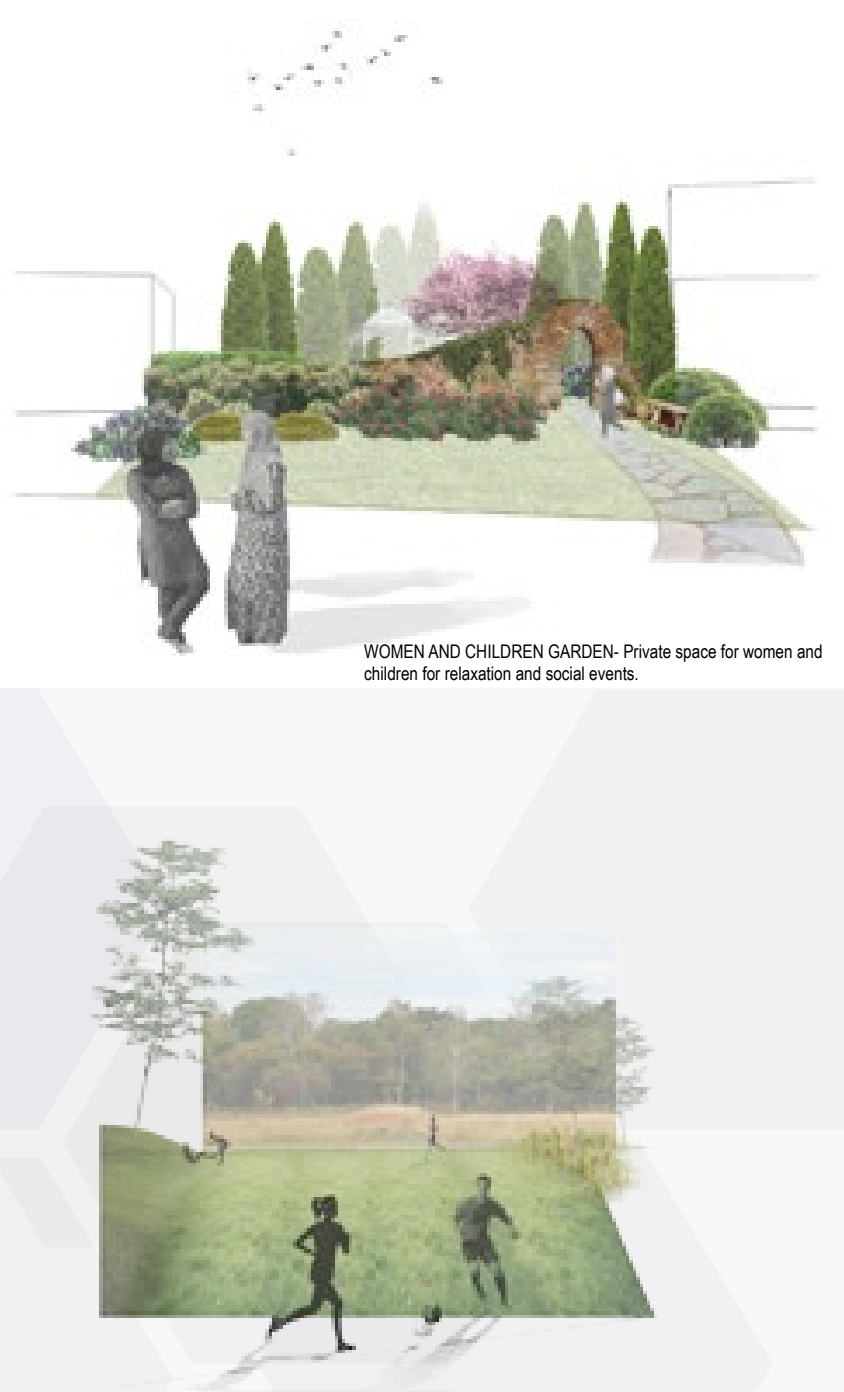

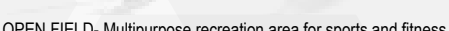
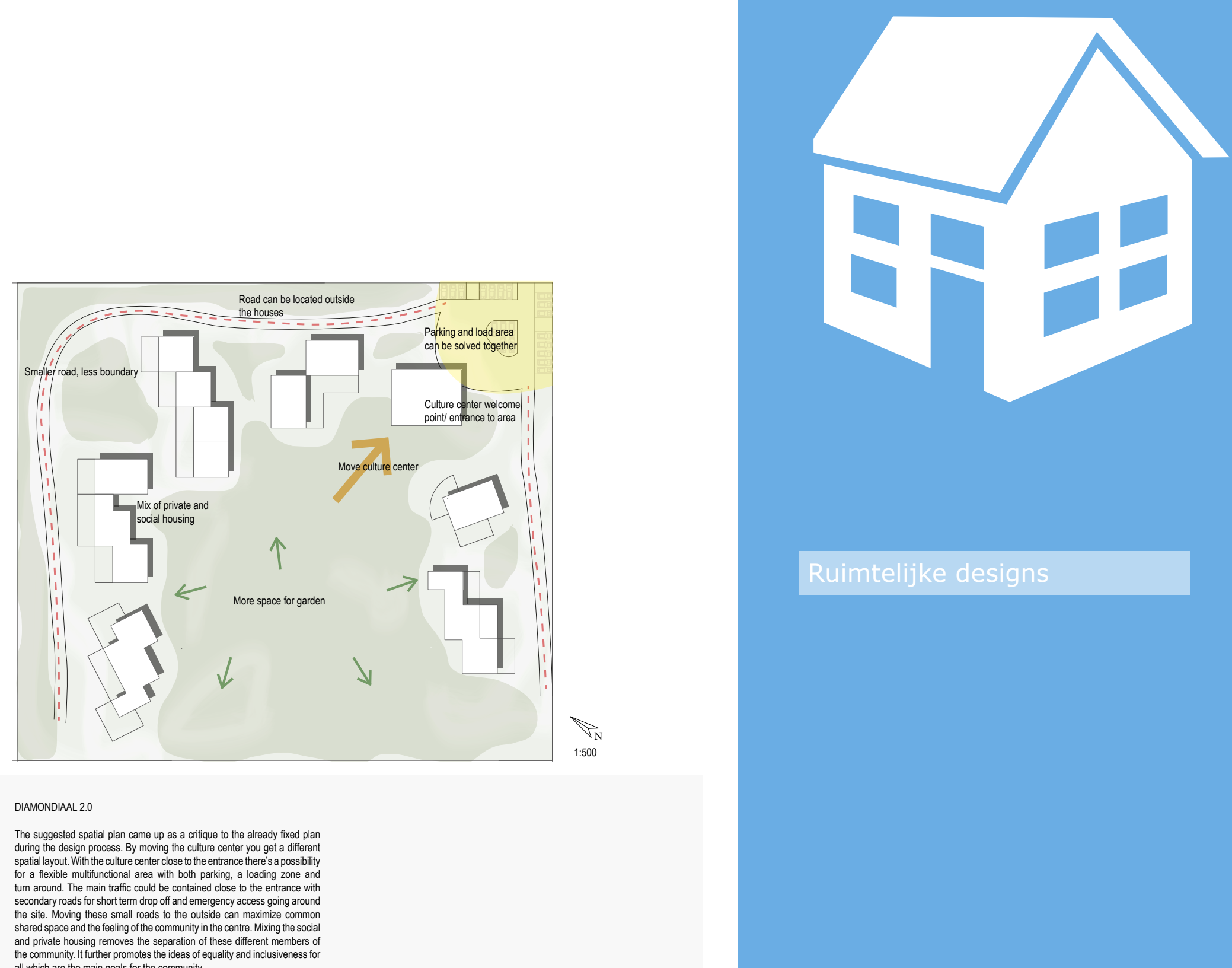

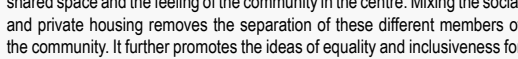

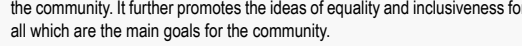

NEXT STEPS

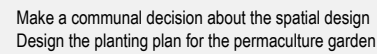

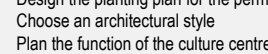

Design your oun pirviate arden

Organize a working team for th e garcle
Start growing plants (weeds) now!

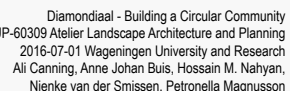

